\title{
アルミニウム合金溶接継手の疲労 に関する最近の趨勢*
}

\section{竹内 勝治**}

Recent tendency for fatigue of aluminum weld joints*

Katsuzi TAKEUCHI**

\section{1.はじめに}

最近，我が国では鉄道車両，小型船舶を始めとしてア ルミニウム溶接構造物の実績が高く評価され，これと関 係して溶接継手の疲労強度がますます重要視されるよう になつてきた。いつぽう，欧米諸国においては疲労関倸 も含めてアルミニウム溶接構造規格の再検討が行われて おり，かつ欧米間の規格の差を少しでも解消しょうとす る試みがある。また，公表された溶接継手の疲労データ を統計的に処理して疲労設計規格作成および研究者の利 用に便宜をはからうとする国際的な委員会 (CAFDEE) も設立された。

著者は本年 5 月 24 日 26日にわたり西独 München 市 で開催された第 2 回「アルミニウム溶接物国際会議」の 概要について既に報告” したが，本報は同会議における 疲労関係発表論文から最近の趨勢についてまとめたもの であり，CAFDEE と S-N 曲線の評価方法，疲労設計規 格の再検討, 疲労強度の改善, および各種溶接継手の疲 労強度等について述べる。

\section{GAFDEE と S-N 曲線の評価方法}

\section{1 アルミニウム疲労データ交換・評価委員会} (CAFDEE) の活動状況

最近10年間にわたり，米国アルミニウム協会 $(\mathrm{AA})$ の 援助により溶接研究協議会 (WRC)のアルミニウム合金 委員会が溶接継手の疲労データを広範囲に集め，その疲 労データバンクが米国 Iowa 州立大学に設けられていた。 これが発展して，昭和55年に 国際的な委員会 Committee for Aluminium Fatigue Data Exchange and Evaluation (CAFDEE) が設立され，オーストリア，カナダ， 英国, イタリー, 日本，ノルエー，スイス，西独，米国
の 9 か国が参加し，その目的と活動範囲について R.A. Kelsey らが報告2)している。我が国が CAFDEE に加入 した経緯およびその活動状況については別に報告3)があ り，軽金属溶接構造協会「アルミニウム接合部疲労デー 夕調查委員会」が国内に扮ける疲労データの収集・整理 を行つている。

CAFDEE の目的は，「アルミニウム構造物および部材 の疲労負荷について設計規格を作成する組織や，この分 野で活動する研究者が使用し得る継手の疲労データを収 集・解析する」ことで，必要に応じて適切な設計規格の 開発に要する試験を規格作成組織に勧告することであ る。現在までに,およそ 12,000 個の実験点からなる1, 100 以上のS-N曲線が収集されて抢り，Table 1 亿示す2)。 これらのデータはミグおよびティグ溶接技術の普及が始 まつた 昭和29年以降に 刊行された250編余の論文と報告 書から収集したもので，Table 2 に論文の出所と時期的 分布を示した。

各試験結果に対して疲労データバンクに入れてある情 報は次のようであり，コンピュータ化されている。

疲労データの出典

アルミニウム合金の種類*

Table 1 Aluminum Alloys Represented in CAFDEE Data Bank.2)

\begin{tabular}{lcc}
\hline \hline Series & No. of Test Programs & No. of Data Points \\
\hline 2000 & 57 & 480 \\
3000 & 3 & 36 \\
5000 & 720 & 7315 \\
6000 & 160 & 1415 \\
7000 & 165 & 2570 \\
(Total) & $(1105)$ & $(11816)$ \\
\hline
\end{tabular}

* 昭和 57 年 8 月 30 日軽金属学会関西センターにて発表。

** 住友軽金属工業(株)技術研究所。 
Table 2 Sources of Data in the CAFDEE Data Bank. ${ }^{2)}$

a) Published Reports

\begin{tabular}{lrlrrr}
\hline \hline Country & & & \multicolumn{2}{c}{ Period } \\
\hline Austria & 5 & Italy & 6 & $1954 \sim 1959$ & 4 \\
Belgium & 1 & Japan & 18 & $1960 \sim 1964$ & 26 \\
Canada & 1 & Norway & 3 & $1965 \sim 1969$ & 25 \\
C.S.S.R. & 1 & U.S.S.R. & 22 & $1970 \sim 1974$ & 47 \\
France & 5 & Sweden & 5 & $1975 \sim 1979$ & 70 \\
F. R. Germany & 40 & Switzerland & 1 & $1980 \sim 1982$ & 22 \\
Great Britain & 18 & U.S.A. & 52 & & (Total) \\
Hungary & 5 & (Total) & $(184)$ & & $(184)$ \\
\hline
\end{tabular}

b) Unpublished Reports (U.S.A.)
Private Labs
Government Labs
Government Contracts
13 (Total 75)
15

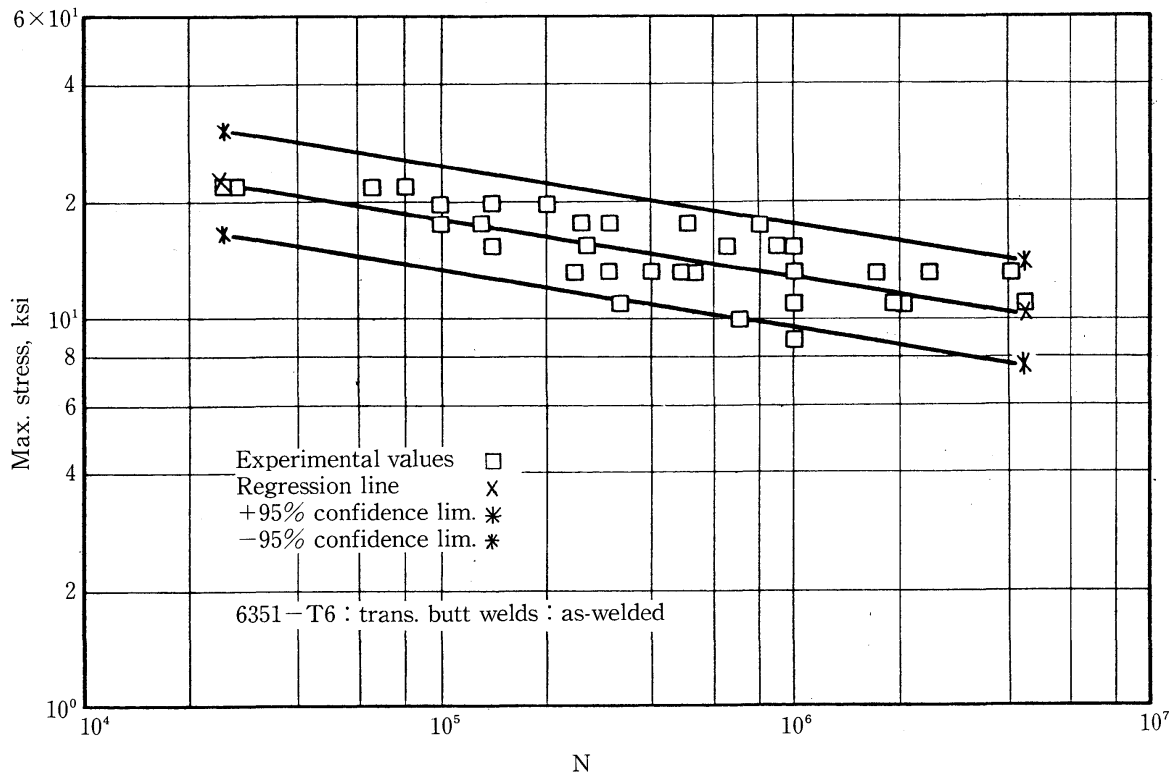

Fig. 1 Plotted data for 6351-T6 butt welds. ${ }^{2)}$

耐力および引張強さ*

試験片の形状と寸法*

継手の形式*

溶接条件*

特殊処理抒よび試験環境*

厚さ*

疲労試験結果（最大応力, 最小応力, 応力範囲, 破壊に至る繰返し数)

上記に掞いて，*印のついたもの（変数）のいかなる 組合せもバンクから抽出可能であり, 出典も含めて試験 シリーズ変数に関するすべての情報と, 制限のない場合 は個々の試験データを提供できる。すべてのデータは解 析されており，応力と破壊に至る繰返し数から直線回帰
最小二乗線を求め，その線の方程式，推定標準誤差，相 関係数を，破壊に至る繰返し数（対数）および下記をも とにして提供する。
(a) 最大応力（直線的）
(b) 応力範囲 ( " " )
(c) 最大応力 (対数)
(d) 応力範囲 ( " " )

さらに，要求のある場合は両対数表示で Fig. 1 のよ らにデータを図示し，最小二乗線および95\%信頼限界線 も表示する。

以上が CAFDEE の活動状況であり，今後も溶接継手 の疲労データの収集・解析を継続するが，さらにボルト 継手, 接着剂継手, 疲労き裂進展データも収集の予定で 


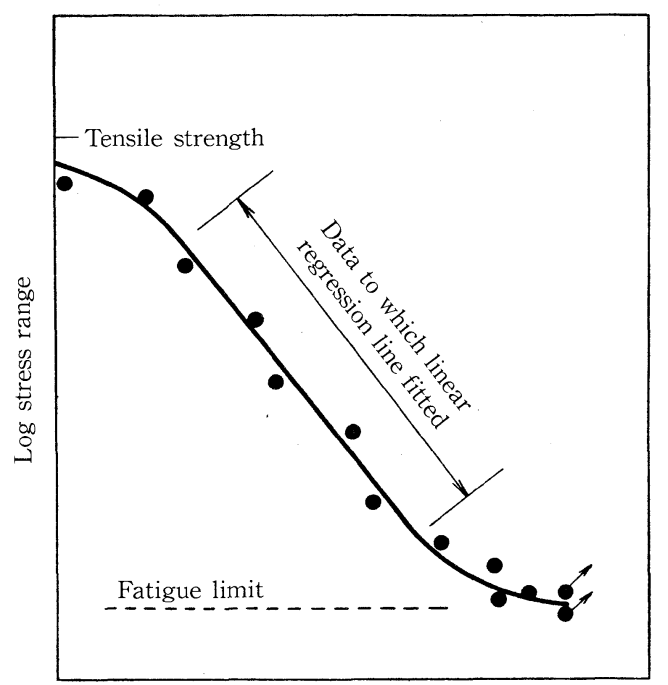

Log endurance, $\mathrm{N}$

Fig. 2 Typical set of fatigue data. ${ }^{4}$

ある。

なお，CAFDEE の問題点の一つは統計的解析と S-N 曲線のモデル化の手法であり，これに関しては2.2 項で 述べる。他の問題点は, 収集した疲労データの殆んどが 小規模な研究室的試験片によるものであつて，実際の溶 接構造物継手に利用し得るものがごく僅かなことであ る。研究室的試験片は継手の前処理, 溶接手順, 局部溶 接処理, 環境および負荷履歴等の溶接特性が疲労強度に 及ぼす影響を評価するのに適するが，これらのデータが 溶接残留応力をもち，また二次的な曲げ応力を受ける実 際の溶接構造物の挙動をいかによく表すかについては余 り明確でない。データバンクにはトラス执よび橋梁部材 について限られたデータがあるが，さらに実物大継手に 関するデータが要求されている。

\section{$2.2 \mathrm{~S}-\mathbf{N}$ 曲線の評価方法}

CAFDEEの問題点の一つは前述したように収集し た疲労データの統計的解析と $\mathrm{S}-\mathrm{N}$ 曲線のモデル化の 手法であり, W. W. Sanders, Jr., S. J. Maddox, D. Kosteas が小委員会を組織して CAFDEE データバンク に使用する手法を検討した。それと関係して米国におけ る疲労データの評価原則, 英国における評価の経験およ び西独における $\mathrm{S}-\mathrm{N}$ 曲線の評価方法等が発表4)されて いる。

1) 米国における疲労データの評価原則

米国では ASTM E468 “金属材料一定応力振幅疲労試 験結果表示方法推奨規格 (1976)”, 同 E 739 “応力一寿命 $(\mathrm{S}-\mathrm{N})$ ，ひずみ一寿命 $(\varepsilon-\mathrm{N})$ 疲労データの直線的表示に よる統計的解析方法 (1980)" 扎よび陸軍規格 MIL-HDB K-5 C “航空宇宙機体構造用金属材料と部材 (1976)” の
3 規格が疲労データの評価方法として用いられている。 E 468 は定応力疲労試験で, アルミニウム合金溶接継 手の疲労の基礎として用いられているが，疲労データの 解析は実験者の提供する情報, 例えば母材の材質と規格, 強度, 表面状況, 溶接条件と余盛形状, 試験条件等に影響 を受ける。E 739は統計的手法によつて S-N 曲線を解析 するもので, 応力 $\mathrm{S}$ を一定とした場合, 破壊までの繰返 し数 $\mathrm{N}$ は対数正規分布と仮定する。これによつて破壊確 率 S-N 曲線が得られたとしても，その S-N 曲線は最小 二乗法による線に平行でなく，かつ信頼限界は $95 \%$ まで といえる。Weibull 分布が疲労データに適用でき, かつ 突出したデータや保留する実験結果があるとすれば, Maximum Likelihood Method による解析が必要と述べ ている。MIL-HDBK-5C は荷重または変位調節試験装 置を用いて $\mathrm{N}=10^{3} \sim 10^{7}$ の間で破壊する疲労データから 解析しようとするもので，アルミニウム合金溶接継手に 適用する場合は基準となる $\mathrm{S}-\mathrm{N}$ 曲線が重要となる。

2) 英国における設計用疲労データ評価に関する経験 英国における疲労データの統計的解析方法としては BS 2846 “データの統計的処理 (1976)”执よびE. S. D. U. Data Sheet Numbers 68,014〜68,017(1968)”がある。 これらは設計規格の基礎を得るために出典の異なるデー 夕を解析するといらよりも，充分に限定かつ調節された 条件下に打ける特殊な設計のためのものといえる。IIW の第18委員会のワーキング・グループ 1 は下記の 3 条件 について疲労データの統計的解析を検討しており，まだ 最終結論に至つていないが，これらの処理に当つて単純 な統計的手法を見出していない ${ }^{5)}$ 。特に最大の問題とな

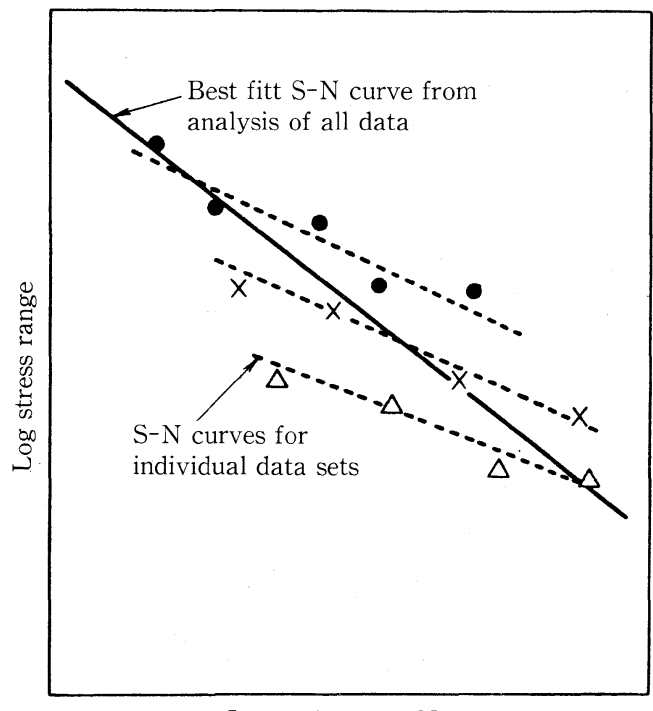

Log endurance, $\mathrm{N}$

Fig. 3 Situation requiring correction of slope of S-N curve fitted to all data. ${ }^{4}$ 


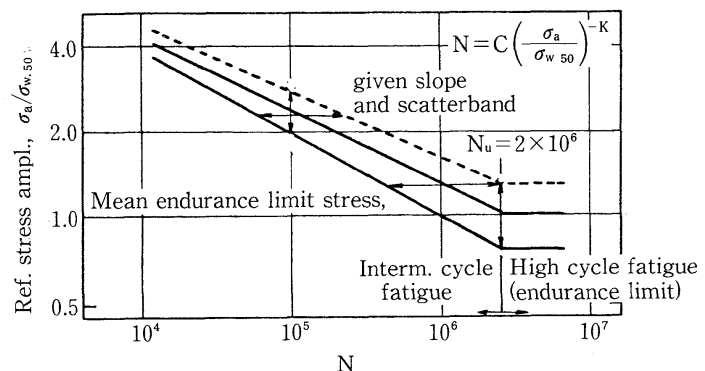

Fig. 4 Normalized S-N curve. ${ }^{4)}$

つているのは下記の $(\mathrm{c})$ の場合であり，設計規格の作成に おいてその評価を欠くことができないからである。

(a) 同じ試験片で，同じ研究所で試験された多くの結 果

(b) 同様の試験片で応力集中が(a)より大きく，主とし て一研究所で長年にわたり得られた多くの結果

(c) 同様な試験片で長年にわたり多くの異なつた研究 者によつて得られた結果

疲労デー夕解析における基礎は両対数表 示で $\mathrm{S}-\mathrm{N}$ 曲 線を直線，Nは対数正規分布として最適の回帰直線を検 討するわけであるが，Fig. 2 に示すよ5に耐力を越える 部分と疲労限度に近いところが直線にならないといら問 題がある。

次は出典の異なる疲労データを解析する場合, 各標本 が同一母集団に属するとみなして差支えないか，という 問題がある。鋼溶接継手で同じ形状，同じ負荷条件から 得た数種のデータを解析すると，Fig. 3 亿示すように個 々の標本の S-N 曲線の傾斜と同一母集団とみなした場 合のそれとが異なつた例がある ${ }^{6)}$ 。アルミニウム溶接物 は平均応力, 溶接で生じた残留応力の影響および平均応 力がある 場合のき 裂進展速度感受性が 大きいという 報 告?があるため，鋼溶接物の場合より前述したよう.な例 が表れやすいと考え，これらの影響について S-N 曲線 の傾斜との関係において解説している。また同じ集団の データで注意を要するのは板厚の相違, 溶接線の配列と 目違い，試験環境である。

3）西独における $\mathrm{S}-\mathrm{N}$ 曲線の評価方法

疲労試験の計画や解析に関し規定された勧告や規格は なく, また疲労試験は高度の経験と経費を必要とするの で数少ない研究所で伝統的に実施されている。最近, 注 目をあびているのは E. Haibach" による “標準化 S-N 曲線”であり，主として鋼溶接継手の疲労データの評価 に用いられ，Fig. 4 に示す。この評価方法はドイツ鉄鋼 委員会 (DASt) の疲労分科会で数年前から原案を検討し ている。

アルミニウム合金溶接継手の疲労データが合金の相 違，溶接手法その他によつて比較的大きな散らばりをも
Table 3 Alloys covered by CP 118. ${ }^{10}$

\begin{tabular}{lcc}
\hline CP 118 & $\begin{array}{c}\text { Alloy } \\
\text { Aluminum } \\
\text { Association }\end{array}$ & $\begin{array}{c}\text { Covered by } \\
\text { Fatigue Rules ? }\end{array}$ \\
\hline H30 & 6351 & Yes \\
N8 & 5083 & Yes \\
H20 & 6061 & Yes \\
H15 & 2014 & Only unwelded members. \\
H17 & 7020 & Yes \\
N4 & 5052 & Yes \\
N5 & 5154 & Yes \\
N6 & 5056 & Yes \\
H9 & 6063 & Only welded members. \\
\hline
\end{tabular}

つことは 1960年代の実験において既知であり ${ }^{9)}$ ，当時の ASTM 推奨方法を一部だけ参考にして 統計的因子の検 討, 回帰分析, P-S-N 線図等も求められた。現在, 統計 的回帰分析手法はコンピュータ・プログラムにまとめて あり，P-S-N線図とともに解析データをプロットするよ らになつている。なお, Max. Likelihood Method も含め て最近の統計的解析の動向について触れているが, 省略 する。

\section{3. 疲労設計規格の再検討}

\section{1 英国における疲労設計規格の問題点}

英国ではアルミニウム溶接構造に関して 3 規格 (BS CP 118 : アルミニウムの構造物への使用, BS 5500 : 火 なし溶融溶接圧力容器, BS PD 6493: 溶融溶接継手の欠 陥受入れ水準の誘導に対する指針）があり，現在，改正 を検討中という。S.J. Maddox ${ }^{10)}$ は各規格の特色と改正 される動向を鋼構造規格との関連において述べている。

1） BS CP 118 アルミニウムの構造物への使用

CP 118 注照明柱, 圧力容器を除く各種構造物へのアル ミニウム合金の使用を規定したもので，1969年に公表， 1973年に改正されている。Table 3 は合金の種類と疲労 設計応力の規定の有無を示す。

CP 118は一般の疲労設計規格と同様, 溶接継手に対し て級別システム区分を採用しており, 類似の疲労強度を もつ溶接継手類はある級に集め, 疲労強度が低下する順 に $1 \sim 9$ 級としており，1 級は母材である。この級別シ ステムを広範囲のデータから詳しく解析されている鋼溶 接継手の設計規格 ${ }^{11), 12)}$ のように改正すべしというのが Maddox の提案である。その理由鋼とアルミニウムの 相対的疲労強度が同じと仮定できるからであるが，現実 には鋼溶接継手の級別システムを与えている BS 5400 と Table 4 に示すように異なつている ${ }^{11}$ 。これらに関して は 3.2 項で述べるが，CP 118を改正する場合には鋼溶接 継手に用いられている級別線に沿つて詳しい提示が必要 
Table 4 Comparison of Classification Systems in Aluminium and Steel Rules. ${ }^{10}$

\begin{tabular}{|c|c|c|}
\hline \multirow[b]{2}{*}{ Description of detail } & \multicolumn{2}{|c|}{ Class } \\
\hline & CP 118 & BS $5400^{12)}$ \\
\hline Plain material, finished edges. & 1 & $\mathrm{~A} / \mathrm{B}$ \\
\hline Longitudinal butt welds, ground flush. & 2 & B \\
\hline Transverse butt welds, ground flush. & 2 & $\mathrm{C}$ \\
\hline $\begin{array}{l}\text { Continuous longitudinal butt welds without } \\
\text { stop/start. }\end{array}$ & 3 & $\mathrm{C}$ \\
\hline $\begin{array}{l}\text { Transverse butt welds, good overfill shape (height } \\
\text { limited to } 3 \mathrm{~mm} \text { in CP } 118 \text {; good shape achieved by } \\
\text { choice of welding procedure in BS } 5400 \text { ). }\end{array}$ & 3 & $\mathrm{D}$ \\
\hline $\begin{array}{l}\text { Continuous longitudinal fillet welds without } \\
\text { stop/start. }\end{array}$ & 4 & $\mathrm{C}$ \\
\hline $\begin{array}{l}\text { Transverse butt welds without overfill height/shape } \\
\text { limitation. }\end{array}$ & 4 & $\mathrm{E}$ \\
\hline Transverse butt welds made from one side. & 5 & No included \\
\hline $\begin{array}{l}\text { Transverse butt welds made on permanent backing } \\
\text { strips attached with full-length fillet welds. }\end{array}$ & 5 & $\mathrm{~F}$ \\
\hline Transverse non-load-carrying fillet welds. & 5 & $\mathbf{F}$ \\
\hline Cover plate on beam flange. & 5 & G \\
\hline $\begin{array}{l}\text { Transverse butt welds made on permanent backing } \\
\text { strips not attached with fillet welds. }\end{array}$ & 6 & $\mathrm{~F}$ \\
\hline $\begin{array}{l}\text { Transverse load-carrying full penetration weld in } \\
\text { cruciform joint. }\end{array}$ & 6 & $\mathrm{~F}$ \\
\hline $\begin{array}{l}\text { Transverse load-carrying partial penetration or } \\
\text { fillet weld in cruciform or lap joint (weld toe } \\
\text { considered). }\end{array}$ & 6 & $\mathbf{F} 2$ \\
\hline $\begin{array}{l}\text { Transverse load-carrying full penetration weld in } \\
\mathrm{T} \text {-joint. }\end{array}$ & 7 & $\mathbf{F}$ \\
\hline $\begin{array}{l}\text { Transverse load-carrying partial penetration or } \\
\text { fillet weld in T-joint (weld toe in stem considered). }\end{array}$ & 7 & $\mathrm{~F} 2$ \\
\hline Continuous longitudinal fillet welds with stop/start. & 7 & $\mathrm{D}$ \\
\hline $\begin{array}{l}\text { Discontinuous longitudinal non-load-carrying fillet } \\
\text { or butt welds. }\end{array}$ & 8 & $\mathbf{E}$ \\
\hline Web to flange weld at cope-hole. & 8 & $\mathrm{~F}$ \\
\hline Fillet welded web stiffeners. & 8 & $\mathrm{E}$ \\
\hline Longitudinal non-load-carrying fillet welds. & 8 & $\begin{array}{l}F \text { or } F 2 \text { if attach- } \\
\text { ment more than } \\
150 \mathrm{~mm} \text { long. }\end{array}$ \\
\hline Attachment to edge of stressed member. & 8 & G \\
\hline $\begin{array}{l}\text { Transverse load-carrying partial penetration or fillet } \\
\text { welds (weld throat considered). }\end{array}$ & 8 & W \\
\hline Longitudinal load-carrying weld. & 9 & G \\
\hline
\end{tabular}

で，溶接継手に発生するき裂の位置は Fig. 5 に示すよ らにそれぞれあつて，その使用設計 S-N 曲線が 異なる ことによる。

疲労設計応力は $N=10^{5} \sim 10^{8}$ にわたつて最大応力 $\sigma_{\max }$ と応力比 $R\left(=\sigma_{\min } / \sigma_{\max }\right)$ で示されているが, $R=\left(\sigma_{\mathrm{m}}-\right.$ $\left.\sigma_{\mathrm{a}}\right) /\left(\sigma_{\mathrm{m}}+\sigma_{\mathrm{a}}\right)$ と定義すべきであると主張している。 $\sigma_{\text {min }}$ は最小応力, $\sigma_{\mathrm{m}}$ 汇平均応力, $\sigma_{\mathrm{a}}$ は応力 振 幅である。 CP 118 における $R$ の影響は級別と繰返し数によつて異 なつている。例えば, $N=2 \times 10^{6}$ の $\sigma_{\mathrm{a}}$ は $R=0$ から 0.5 まで約 $20 \%$ 低下し， $R=0$ からー1まで $40 \%$ 以上増加し
ている。しかし，鋼構造規格が再検討したように，アル ミニウム合金溶接継手の疲労強度に及ぼすRの影響は見 直す必要があると述べており，現行規格作成の基礎とな つた疲労試験片が実際の溶接構造物で予測される引張残 留応力とくらべて余りにも小さすぎる值をもつものであ つたことに誤解の原因がある。

CP 118 における疲労設計応力を S-N 曲線で表示した のが Fig. 6 である（図中の級別は Table 4 参照）。規格 は $N=10^{8}$ における值より低い負荷応力を無視できると しているが，実際の変動荷重下ではその応力が重複され 


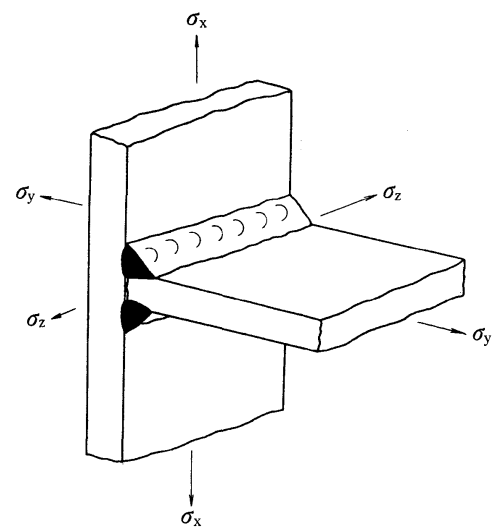

Stess Possible sites for fatigue cracking Class

$\begin{array}{lll}\sigma_{z} & \text { Weld toein plarte A } & 7\end{array}$

$\sigma_{y}$ Weld toe in plate B 7

Weld throat 8

$\sigma_{z}$ Wald ripples in continuous 4 automatic weld

Stop/start in cotinuous weld 7

Weld eod if discontinuous weld 8

Weld end if short weld 8

Fig. 5 Example of welded joint classification in BS CP118 (1969). ${ }^{10)}$

て損傷を与えるから，鋼構造規格 ${ }^{12)}$ が採用しているよう に S-N 曲線の外挿 $\left(\mathrm{N}=10^{7}\right.$ で $\mathrm{S}-\mathrm{N}$ 曲線の傾きを変え る）を考慮する必要がある。また， $N=10^{5}$ 以下への外挿 をひずみによる低サイクル疲労き裂発生の観点から認め ていないが，これも不必要な制限であつて静的設計応力 限界（静的許容応力）が保証してくれよう。仮に応力集 中により局部的な塑性ひずみが発生したとしても, 降 伏現象は周囲の弾性材料によつて制限を受ける ${ }^{13), 14)}$ の で， S-N 曲線を適用できる。なお，累積損傷比に関して は鋼と同様 $\Sigma n / N \leqq 1$ を用い，特に変更する理由もない が今後の研究が必要であると述べている。

2) BS 5500 火なし溶融溶接圧力容器

BS 5500 では, 1981年からアルミニウム製圧力容器の 疲労設計が付録 $\mathrm{C}$ に記されており, 以前は鋼製容器のみ であつた。しかし，全体の付録事項について見直し中で あり, 将来変更されて鋼構造規格 ${ }^{12)}$ と同じようになる可 能性がある。

疲労設計規格の考え方は ASTM 規格と同じであり， 材料の S-N曲線は応力集中（溶接継手も含めた構造的不 連続）と関連して用いる。突合せおよび隅肉溶接の余盛 端の応力集中率は少なくとも2.5と仮定し, 仕上げた場合 はそれより少さくとる。設計 S-N 曲線は 鋼のそれを 縦 弾性係数の比 3 で除して得ており, $100^{\circ} \mathrm{C}$ 以下の使用に 限定している。

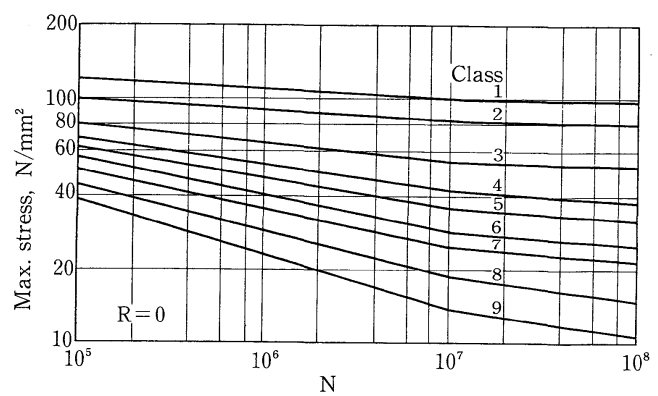

Fig. 6 Set of design $\mathrm{S}-\mathrm{N}$ curves for $R=0$ from BS CP 118 (1969). ${ }^{10)}$

3） BS PD 6493 溶融溶接継手の久陷受入れ水準の 誘導に対する指針

構造物の疲労強度は溶接欠俩の存在によつてもつとも 影響を受けるが，アルミニウムに関するものも含めて多 くの研究結果は突合せ継手における気孔とか介在物の存 在が溶接止端の影響にくらべると小さくて無意味なこと を示している。このような現状から，溶接欠陥受入れ水 準は構造物の性能に及ぼす欠陷の影響に基礎をおき，目 的に適合するアプローチが要求される。PD 6493 はフェ ライト执よびオーステナイト鋼，アルミニウム合金の溶 接物に適用され，き裂状（平面的）欠陥と非平面状欠陥 の両者について疲労と不安定破壊の観点からの評価が可 能である。

隅肉溶接その他多くの溶接をもつ構造物の疲労強度に 関して久陷の影響を評価することは，溶接継手の一般設 計規格 BS $5400^{12)}$ と関係する。この規格には溶接継手の 級別 S-N 曲線が示されており，PD 6493を用いると各級 別に相当する欠陷サイズの見当をつけることが可能で， これを品質範疇という。アルミニウム合金溶接継手を検 討する場合, 鋼の疲労設計応力を 3 で除すればよいが, 得 られた S-N 曲線は現行 CP 118 と異なつている (Table 4 参照, CP 118 は改正されて同じ級別表示となろう)。ア ルミニウムの場合の非平面状欠陥水準と相当する疲労強 度の関係を Table 5に示す。平面状欠陥の影響は単純に 表示できないが，中央位置欠宿の例を Fig. 7 に示す。

Maddox は以上の検討結果から, 各規格間に考え方と 設計応力に相違がなく，かつ鋼とアルミニウムの規格が 相似であることが必要と述べている。

\section{2 疲労設計規格の再検討と提案}

鋼構造疲労設計規格が最近改正されたこと ${ }^{12), 15)}$ と関 連して ECCS (欧州鉄鋼構造製品代表者会議)，IIW，BSI 等もアルミニウム合金溶接構造規格の制定もしくは改正 を考慮中であり，3.1 項と関連して S.J. Maddox は鋼 構造疲労設計規格がアルミニウム合金に利用できないか という提案をしている ${ }^{16)}$ 。その理由として，アルミニウ 
Table 5 Acceptance Levels for Non-planar Welding Defects from BS PD 6493.10)

\begin{tabular}{|c|c|c|c|c|c|}
\hline \multirow[b]{2}{*}{$\begin{array}{c}\text { Quality } \\
\text { Category }\end{array}$} & \multirow[b]{2}{*}{$\begin{array}{l}\text { Equivalent } \\
\text { Class (see } \\
\text { Table 4) }\end{array}$} & \multirow[b]{2}{*}{$\begin{array}{l}\text { Constant } \\
\text { in } \mathrm{S}-\mathrm{N} \\
\text { Curve } \\
\text { (1) }\end{array}$} & \multirow[b]{2}{*}{$\begin{array}{l}\text { Maximum length } \\
\text { of slag } \\
\text { inclusion }^{(2)}, \mathrm{mm}\end{array}$} & \multicolumn{2}{|c|}{ Maximum buried porosity levels } \\
\hline & & & & $\begin{array}{l}\% \text { of area of } \\
\text { radiograph }^{(3)}\end{array}$ & $\begin{array}{l}\text { Individual pore } \\
\text { diameter, } \mathrm{mm} \text {. }\end{array}$ \\
\hline $\mathrm{Q}^{0}$ & above $\mathrm{D}$ & $>5.65 \times 10^{10}$ & 1.5 & 0 & 0 \\
\hline Q1 & $\mathrm{D}$ & $5.65 \times 10^{10}$ & 2.5 & 3 & $\begin{array}{l}\text { Lesser of } 6 \mathrm{~mm} \text { or } \\
\text { thickness } \\
4\end{array}$ \\
\hline$Q^{2}$ & $\mathrm{E}$ & $3.84 \times 10^{10}$ & 4 & 3 & " \\
\hline Q3 & $\mathrm{F}$ & $2.35 \times 10^{10}$ & 10 & 5 & " \\
\hline Q4 & $\mathrm{F} 2$ & $1.60 \times 10^{10}$ & 35 & 5 & " \\
\hline Q5 & $\mathrm{G}$ & $0.91 \times 10^{10}$ & No maximum & 5 & " \\
\hline Q6 & $\mathrm{W}$ & $0.56 \times 10^{10}$ & " & 5 & " \\
\hline Q7 & $<\mathrm{W}$ & $0.37 \times 10^{10}$ & " & 5 & " \\
\hline Q8 & " & $0.23 \times 10^{10}$ & " & 5 & " \\
\hline Q9 & " & $0.14 \times 10^{10}$ & " & 5 & " \\
\hline Q10 & " & $0.09 \times 10^{10}$ & " & 5 & " \\
\hline
\end{tabular}

(1) Equation has form (stress range in $\mathrm{N} / \mathrm{mm}^{2}$ ) ${ }^{3} \mathrm{~N}=$ constant.

(2) Tungsten inclusions do not affect fatigue strength and need not be considered.

(3) $5 \%$ is set as the minimum acceptable level to ensure that more important defects are not masked by porosity during inspection.

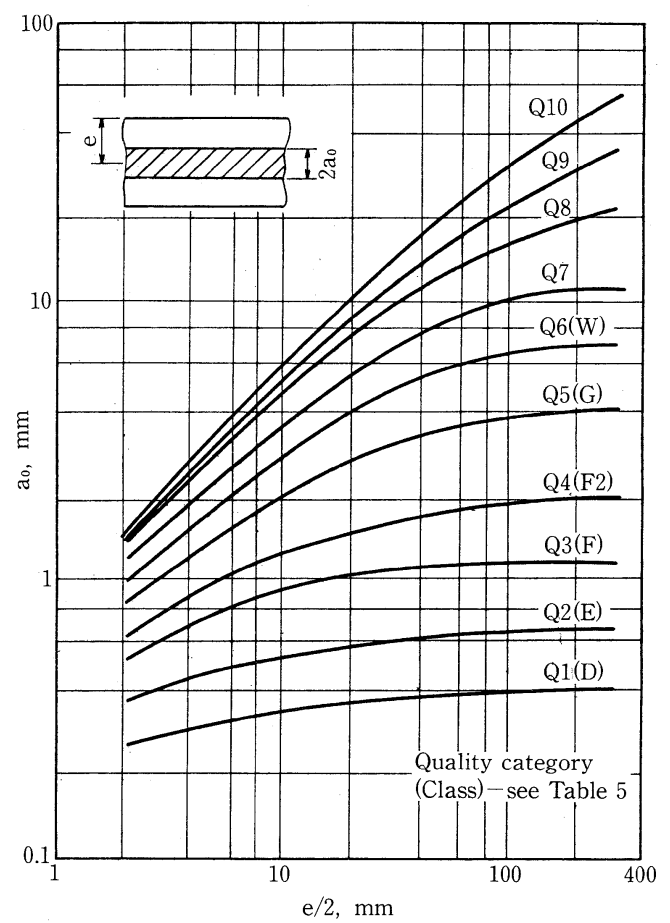

Fig. 7 Curves relating planer defect size and fatigue strength for defect at mid-thickness from BS PD $6493(1980) .{ }^{10)}$

ム合金溶接継手の疲労寿命は疲労き裂の進展に支配さ れ?,17)，結果的にみて溶接されたアルミニウム合金と鋼 の疲労挙動に影響する因子は全く同じであるから，両者
のき裂進展速度の相違に従つて設計応力を調整すれぼ鋼 構造疲労設計規格をアルミニウム合金溶接継手に適用で きる可能性がある。両者の疲労き裂進展データは $\Delta \mathrm{K} / \mathrm{E}$ において関係がある ${ }^{18), 19)}$ から, 鋼の疲労設計応力を 3 で 除すればよいこととなり，この置換に Maddoxは次の仮 定を設けている。

仮定 $1 ：$ アルミニウム合金溶接継手の疲労強度は鋼の 同じ継手に対する值の $1 / 3$ である。

仮定 2 : 溶接継手の相対的疲労強度は鋼とアルミニウ ム合金と同じである。

仮定 $3:$ アルミニウム合金構造物の溶接継手は, 負荷応 力と組合せた場合に疲労強度が平均応力に無関係となら しめるような効果をもつ高引張残留応力をもつている。

仮定 4 : アルミニウム合金溶接継手の疲労限度は同じ 形状の鋼溶接継手の值の $1 / 3$ である。

仮定 5 : アルミニウム合金と鋼の同一形状溶接継手の 疲労データのばらつきは同じである。

仮定 6 : 最大負荷応力が静的最大設計応力に等しくな るまで，引張強さに関係なく，すべての合金に対して同 じ設計 S-N 曲線を用いる。

以上の各仮定について文献その他からその妥当性を述 べている。仮定 1 は, 大部分の場合, 溶接継手の疲労寿 命は疲労き裂の発生面が問題となるよりもき裂の進展か らなりたつており, 疲労き裂進展速度 $d a / d N$ は鋼とアル ミニウム合金と同じで $\Delta K / E$ (ただし, $\Delta K$ は応力拡大係数 範囲, $E$ は縦弾性係数) と関係がある。Fig. 8 に示す7),20) 
ように類似の引張強さをもつ材料のそれは同じであり, したがつて，仮定 1 が成立する。

問題は仮定 3 であり, 溶接したままの鋼継手は降伏点 の大きさに近い高引張残留応力が存在している。これに 繰返し荷重を重複することは, 応力振幅は同じであるが 高引張平均応力下における負荷となる。鋼のき裂進展速 度は引張負荷では平均応力と無関係であるから, 最近の 疲労設計規格は応力振幅に基礎をおいている ルミニウム合金の場合は, 溶接による母材の引張強さの

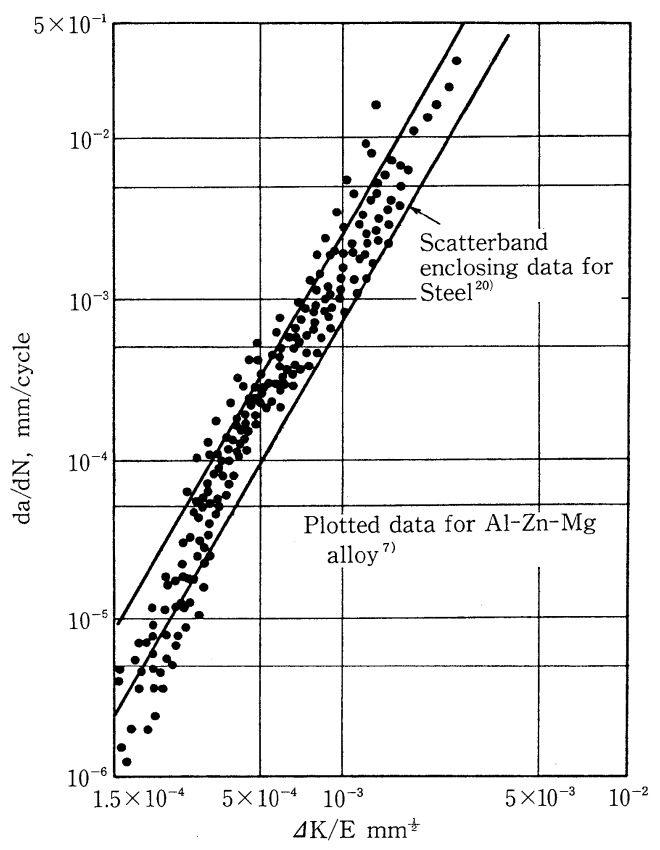

Fig. 8 Comparison of fatigue crack propagation data for Al-Zn-Mg alloy and structural steel obtained under a range of stress ratios $(R=-2$ to $0.5)$, plotted in terms of stress intensity factor based on tensile part of cycle divided by the elastic modulus, $\Delta K_{T} / E .^{16)}$
低下と耐力程度までの残留応力の発生，き裂進展速度が 鋼の場合よりも平均応力に敏感である ${ }^{21)}$ という 2 点か ら，鋼溶接継手のように単純ではない。

残留応力の測定例は比較的少ないが， $\mathrm{Al}-\mathrm{Mg}^{22), 23)}$ お よび $\mathrm{Al}-\mathrm{Zn}-\mathrm{Mg}$ 合金の溶接継手で $150 \mathrm{~N} / \mathrm{mm}^{2}$ 程度の引 張残留応力があるとみなされ，この程度の大きさであれ ば部分片振りか片振り以上で, 疲労強度は負荷平均応力 に関係がない22, 24) といえる。

次に, 残留応力の大きさに影響するのは拘束条件であ り，溶接継手の幾何学的形状と寸法が重要となる。一般 に用いられている溶接継手疲労試験片は小さすぎて，実 際の溶接構造物におけるような高引張残留応力をもつて おらず，平均応力の影響についても誤解を与え勝ちで， 実際の構造物継手の疲労寿命を過大評価する。Fig. 9 10 は5083合金の横方向または長手方向突合せ溶接継手の 例を示す。Fig. 9 の場合, 負荷方向における残留応力の 大きさは試験片の厚さと密接な関係があり，Fig. 10にお いては試験片の幅が影響する。Rの影響は Fig. 9 にお いては試験片の厚さの増加と共に減少し, Fig. 10の場合 は殆んどない。Fig. 9 における疲労強度の差は幾何学的 板厚効果ともみられるが，横方向突合せ継手でその効果 が大きくなるとは考え難いので，残留応力の大きさに及 ぼす試験片寸法の影響とみなされる。溶接構造物は種々 な形態をもち, 実際に発生している残留応力を測定する ことは不可能である。したがつて，高引張残留応力が常 に存在すると仮定するのが現実的で，かつ安全である。 疲労設計応力は高引張残留応力をもつのに充分な大きさ の試験片による疲労データ，もしくは引張片振り，好ま しくは高平均応力をもつ場合のそれに基礎をおくべきで ある。

鋼溶接継手に対する疲労設計規格 ${ }^{12)}$ は前述したように 級別システムを用い，類似の疲労強度をもつ溶接継手は 同じある等級で同一設計 S-N 曲線をもつとみなす。仮定 2 から同じ級別システム合金をアルミニウムに対しても

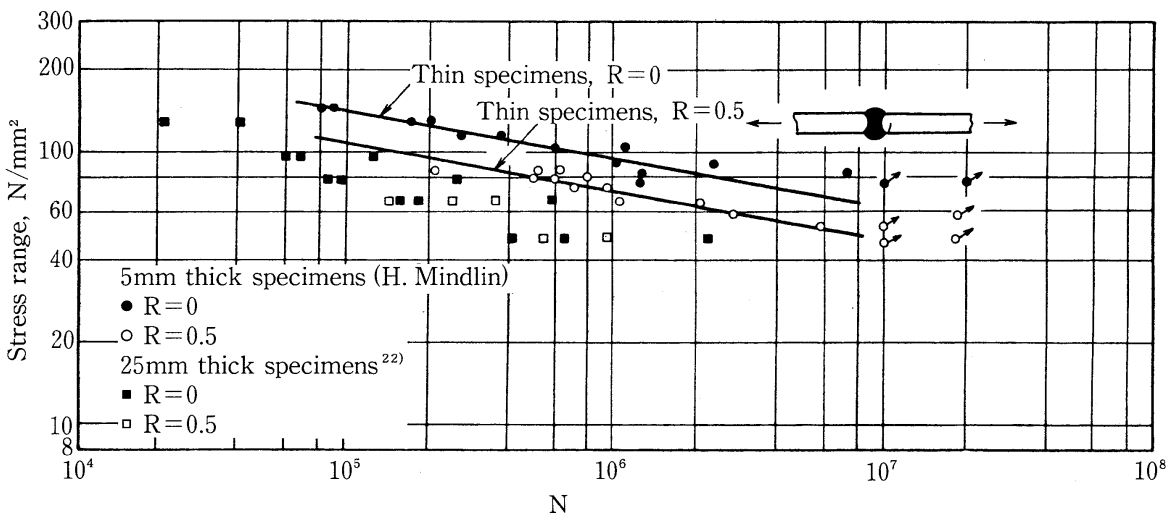

Fig. 9 Fatigue test results for transverse butt welds in 5083 alloy illustrating effect of stress ratio and thickness. $\left.{ }^{16}\right)$ 


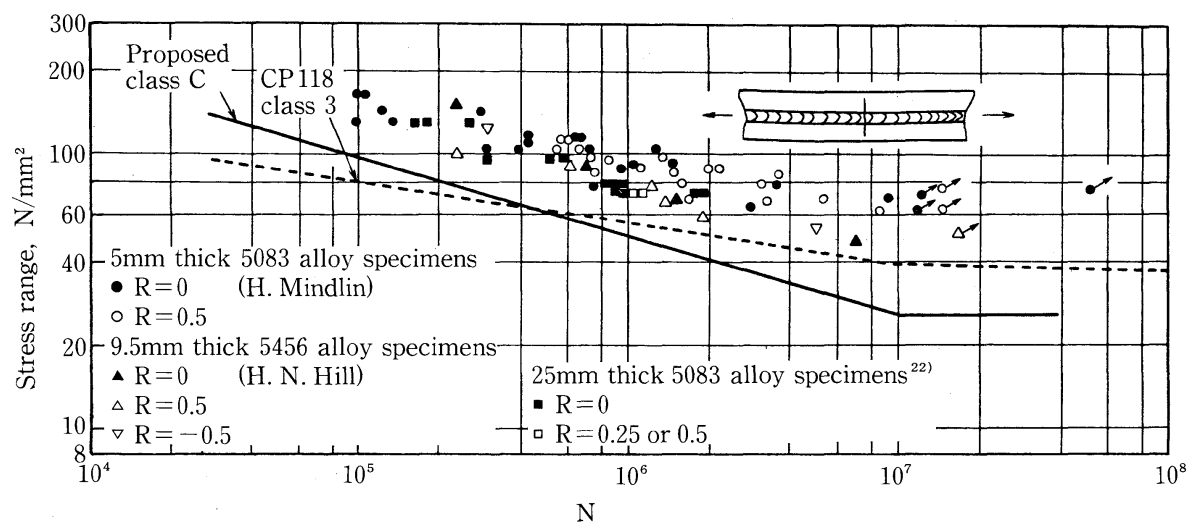

Fig. 10 Fatigue test results for longitudinal butt welds illustrating effect of stress ratio and thickness. ${ }^{16)}$

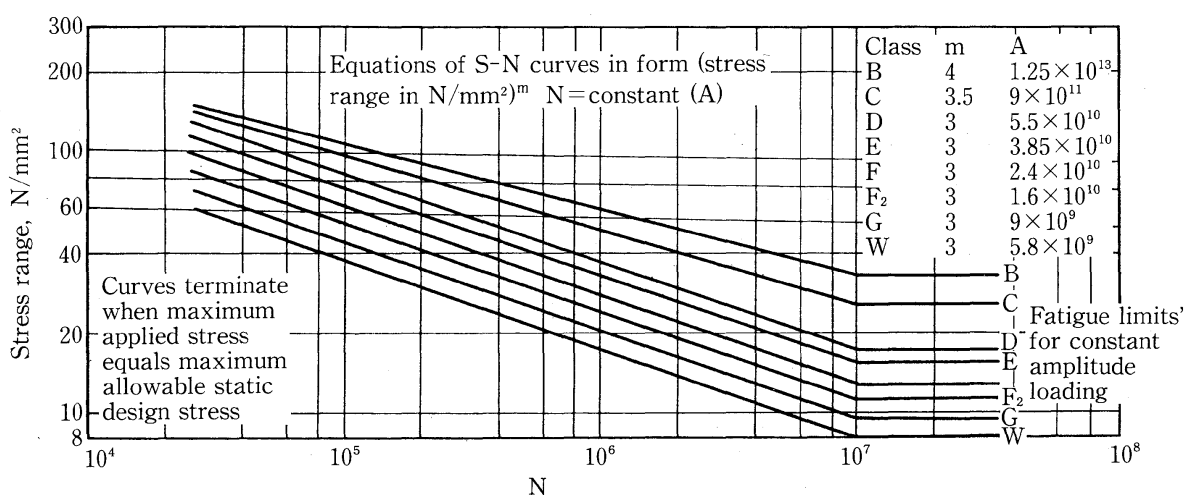

Fig. 11 Proposed design S-N curves for welded aluminium alloys. ${ }^{16}$ )

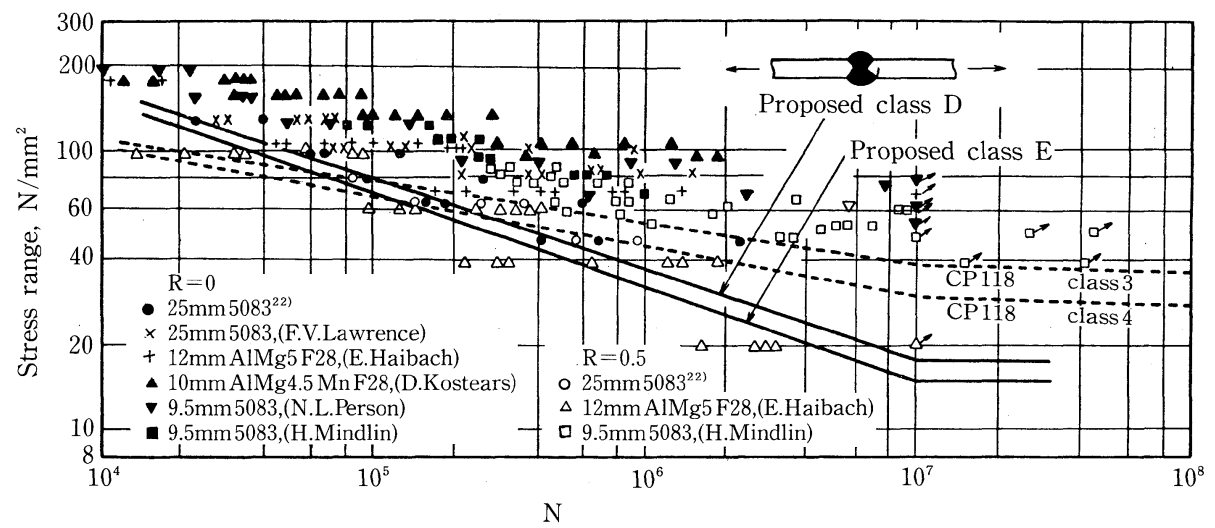

Fig. 12 Fatigue test data for transverse butt welds. ${ }^{16)}$

適用し,これは仮定 1 に従つて 3 で除した応力值であり, 試験片からのデータと実際の構造物によつて代表される ところの条件によつて設計 S-N 曲線で比較検討する必 要がある。提案している設計 S-N 曲線は BS 540012) の 鋼溶接継手のそれを単純に 3 で除したもので, Fig. 11に 示し，これをCP 118に適用 (Table 4 参照) しようとす るものである。Fig. 12〜15 は提案 S-N曲線と現行CP118
のそれとの比較例で，文献データと併せて表示してあ る。

\section{3 突合せ溶接継手の欠陥之規格}

突合せ溶接継手の欠陥（溶接部における外面および内 部における幾何学的不連続，例えば前者は余盛の形状， 過度の目違い等, 後者はき裂, 気孔, 引け巣等の内部欠 陥をさす）は疲労強度に重要な影響を及ぼすわけである 


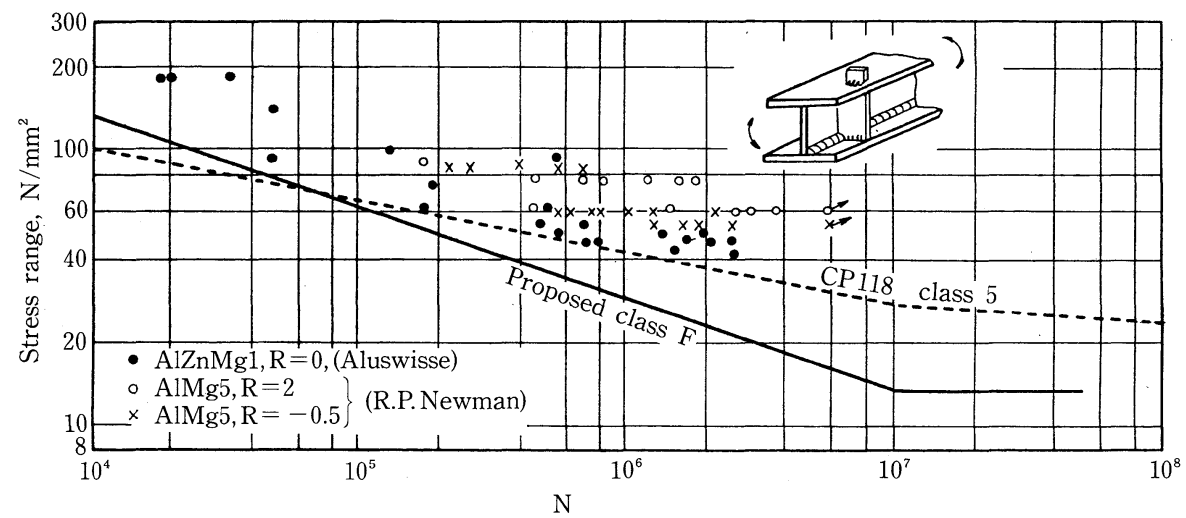

Fig. 13 Fatigue test data for beams with fillet welded stiffeners or surface attachments. ${ }^{16}$ )

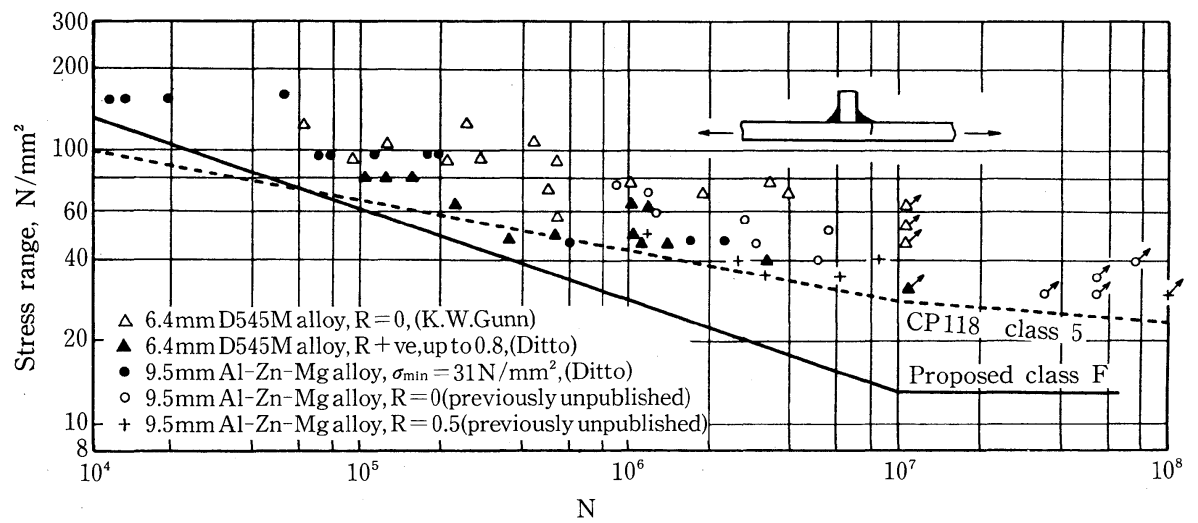

Fig. 14 Fatigue test data for plates with transverse non-load-carrying fillet welded attachments. ${ }^{16}$ )

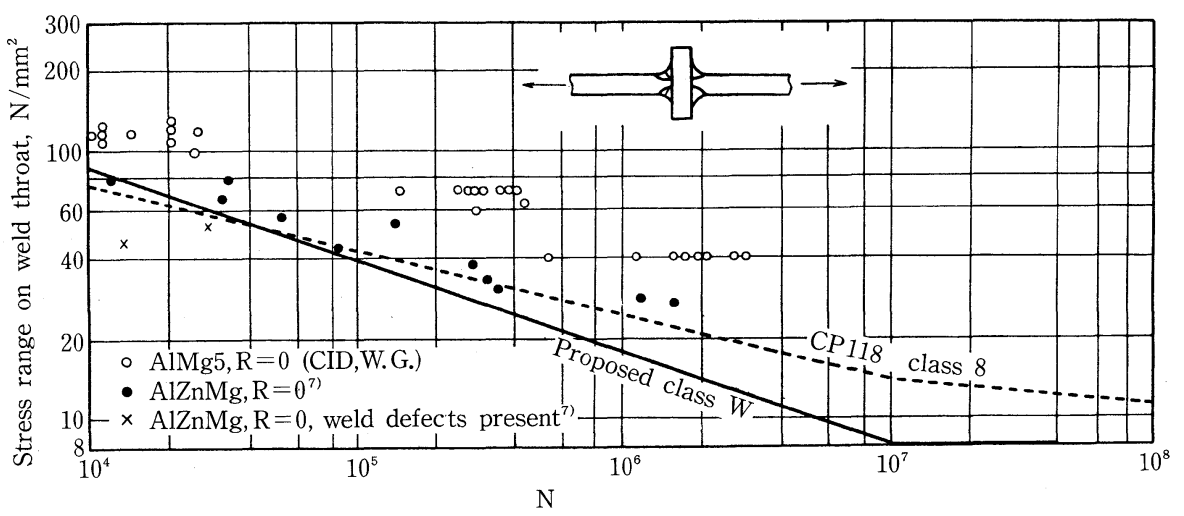

Fig. 15 Fatigue test results for transverse load carrying welds failing across weld throat. ${ }^{16)}$

が，現行規格はその許容範囲が量的にいかに影響するか を表示していない。板厚 $2 \mathrm{~mm}$ の場合における久陥の許 容範囲を DIN 29595，Part 2 (航空宇宙機器用溶融溶接 金属部材，技術基準一許容欠陥）, DIN 8570, Part 4 （溶接 構造一般公差，アルミニウム構造の突合せおよび隅肉溶 接), 掞よびDVS 1611 (鉄道車両構造のX線判定一アルミ ニウム合金溶融溶接）から要約すると Table 6に示す ${ }^{25)}$
ようである (Fig. 16参照)。U. Krüger ら ${ }^{25)}$ は輸送関係 に用いられるアルミニウム溶接構造材として厚さ $2 \mathrm{~mm}$ の $\mathrm{AlZn} 4.5 \mathrm{Mg} 1 \mathrm{~F} \mathrm{35,} \mathrm{AlMgSiCu}$ (6061-T6) 合金を 対象とし, 溶加材は $\mathrm{S}-\mathrm{AlMg} 4.5 \mathrm{Mn}$, ティグ突合せ溶 接で各20種類の試験片シリーズを製作して，これらの点 を検討している。なお，実験内容の詳細は別に報告され てお り ${ }^{26)}$ ，その内容は“非直線的”統計解析と“標準化 
Table 6 Permissible Discontinuities of Welds on $2 \mathrm{~mm}$ Aluminium. ${ }^{25}$ )

\begin{tabular}{|c|c|c|c|}
\hline Discontinuity & $\begin{array}{l}\text { DIN } 29595 \\
\text { part } 2\end{array}$ & $\begin{array}{l}\text { DIN } 8570 \\
\text { part } 4\end{array}$ & Merkblatt DVS 1611 \\
\hline Reinforcement $\Delta a_{1}^{\prime}$ & Max. $2.2 \mathrm{~mm}$ & Max. $2.45 \mathrm{~mm}\left(\mathrm{~b}_{1}=9 \mathrm{~mm}\right)$ & 一* \\
\hline Excessive Penetration $\Delta a^{\prime}{ }_{3}$ & Max. $2.2 \mathrm{~mm}$ & Max. $3.15 \mathrm{~mm}\left(\mathrm{~b}_{2}=6.5 \mathrm{~mm}\right)$ & - \\
\hline Weld Width $b_{1}$ & Min. $4.0 \mathrm{~mm}$ & - & - \\
\hline Misalignment e & $\begin{array}{l}\text { Max. } 0.45 \mathrm{~mm} \\
\text { for plain sheets } \\
\text { max. } 0.70 \mathrm{~mm} \\
\text { for curved sheets }\end{array}$ & Max. $0.20 \mathrm{~mm}$ & - \\
\hline Angular Contraction $\beta$ & - & - & - \\
\hline Root Concavity $\Delta a_{4}^{\prime}$ & Inadmissible & Inadmissible & - \\
\hline Pores & $\begin{array}{l}\text { Max. } 0.6 \mathrm{~mm} \\
\text { dia. (single) }\end{array}$ & - & Max. $0.6 \mathrm{~mm}$ dia. (single) \\
\hline Cracks & inadmissible & - & Inadmissible \\
\hline Tungsten Includings & Max. $1.0 \mathrm{~mm}$ dia. & - & Max. $0.6 \mathrm{~mm}$ dia. \\
\hline
\end{tabular}

* Not defined

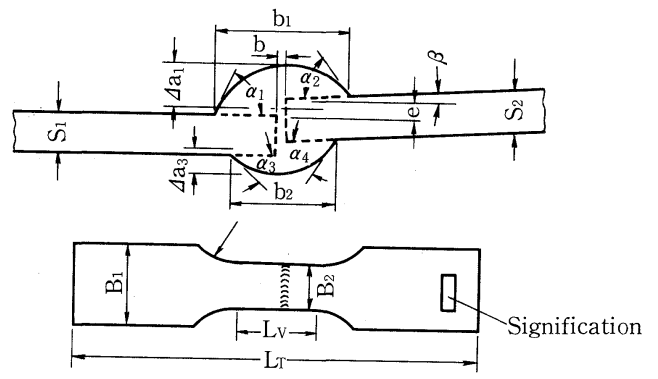

Fig. 16 Sketch for measuring of fatigue specimens. ${ }^{25)}$

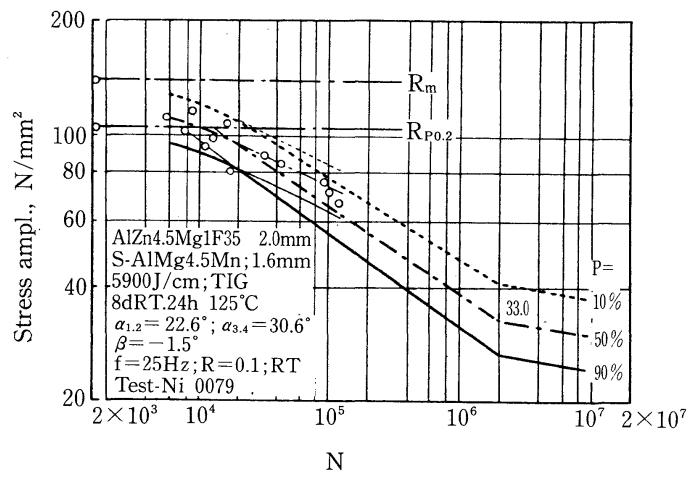

Fig. 17 S-N diagram of butt welded AlZn4.5Mg1 F35 alloy. ${ }^{25)}$

S-N 曲線”の組合せも検討してあるという。疲労試験片 は $\mathrm{AlZn} \mathrm{4.5} \mathrm{Mg} 1$ 合金の場合, 溶接後 7 日以上 常温放 置後 $125^{\circ} \mathrm{C} \times 24 \mathrm{hr}$ の時効(Fig. 17以下の図中表示例：7 $\left.\mathrm{dRT}+24 \mathrm{~h} 125^{\circ} \mathrm{C}\right)$ を施しており, $\mathrm{AlMgSiCu}$ 合金は溶 接のままである。

疲労試験結果は代表例として $\mathrm{AlZn} 4.5 \mathrm{Mg} 1$ 合金の

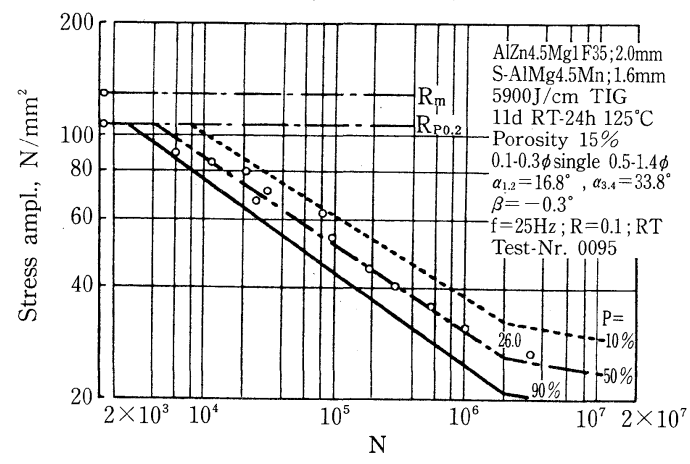

Fig. 18 S-N diagram of butt welded AlZn4.5 Mg1F35 alloy (Porosity 15\%)..25)

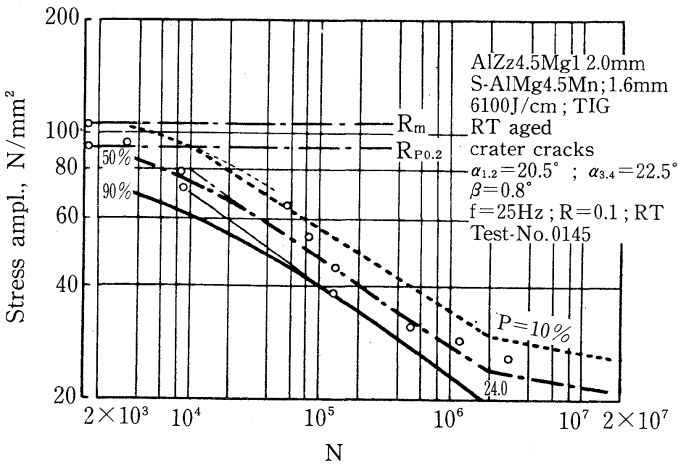

Fig. 19 S-N diagram of butt welded $\mathrm{AlZn} 4.5 \mathrm{Mg} 1$ F35 alloy (Crater cracks). ${ }^{25}$ )

場合を Fig. 17〜19 に示し，各図中に溶接入熱，欠陥の 状況, 試験条件が記入してある。また, Table 7 は目違 いの影響をまとめたものである。

結論として，小型試験片の疲労強度に影響を及ぼす因 
Table 7 Effect of Edge Misalignment. ${ }^{25)}$

\begin{tabular}{|c|c|c|c|c|}
\hline Alloy & $\begin{array}{l}\text { Edge } \\
\text { Misalignment, } \\
\mathrm{mm}\end{array}$ & $\begin{array}{l}\text { Fatigue } \\
\text { Strength } \\
\text { at } 5 \times 10^{4} \\
\text { Cycles } \%\end{array}$ & \multicolumn{2}{|c|}{$\begin{array}{l}\text { Fatigue } \\
\text { Strength } \\
\text { at } 2 \times 10^{6} \\
\text { Cycles } \% \\
\text { A B }\end{array}$} \\
\hline \multirow{6}{*}{$\mathrm{AlZn} 4.5 \mathrm{Mg} 1$} & 0.0, Machined & 100 & 100 & 100 \\
\hline & 0.0 & 79 & 64 & 52 \\
\hline & 0.2 & 88 & 72 & 73 \\
\hline & 0.4 & 59 & 48 & 47 \\
\hline & 0.8 & 45 & 36 & 42 \\
\hline & 0.8 , Machined & 52 & 42 & 59 \\
\hline \multirow{4}{*}{$\mathrm{AlMgSiCu}$} & 0.0 & 100 & 100 & 100 \\
\hline & 0.1 & 88 & 83 & 87 \\
\hline & 0.2 & 85 & 83 & 75 \\
\hline & 0.8 & 65 & 65 & 60 \\
\hline
\end{tabular}

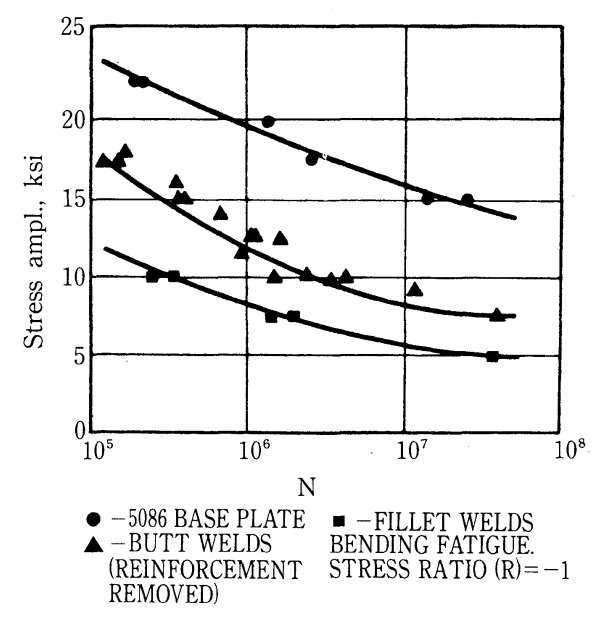

Fig. 20 S-N curves of 5086-H116 base metal and unpeened GMAW weldments. ${ }^{27)}$

子を適切に評価する手段はないが，溶接部形状が疲労強 度に重要な影響を及ぼしており，余盛付根角度，目違い 等で，現行規格の許容範囲では疲労強度の 減少が $40 \%$ に達する。内部欠陷の場合, 容積比 $30 \%$ までの気孔は疲 労強度を $20 \%$ まで減少させ, タングステン巻込み等の影 響は無視して差支えない。試験片中央にあるクレータ割 れは疲労強度をおよそ10\%減少させる。余盛の削除は疲 労き裂の開始点となる気孔が表面に現れるので推奨しな い, と述べている。

\section{4. 疲労強度の改善}

5086合金溶接継手について R. R. Hardy Jr. ら ${ }^{27)}$ と I. J. Polmear ${ }^{28)}$ は疲労強度に及ぼすピーニング加工の影 響を検討している。すなわち，前者は船款材 料 5086- H 116 板突合せ溶接継手の疲労強度が Fig. 20 に示すよう

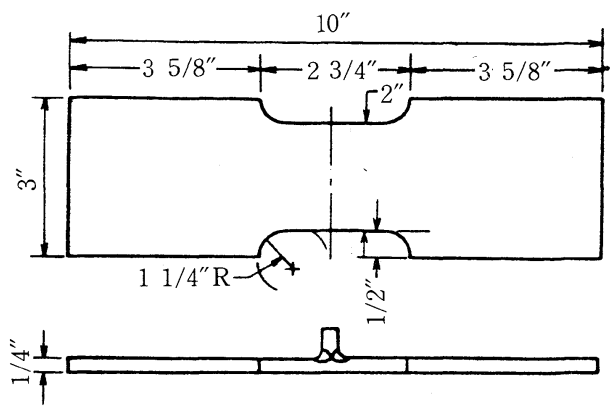

Fig. 21 Flat plate tee fillet-welded specimen (GMAW). ${ }^{27)}$

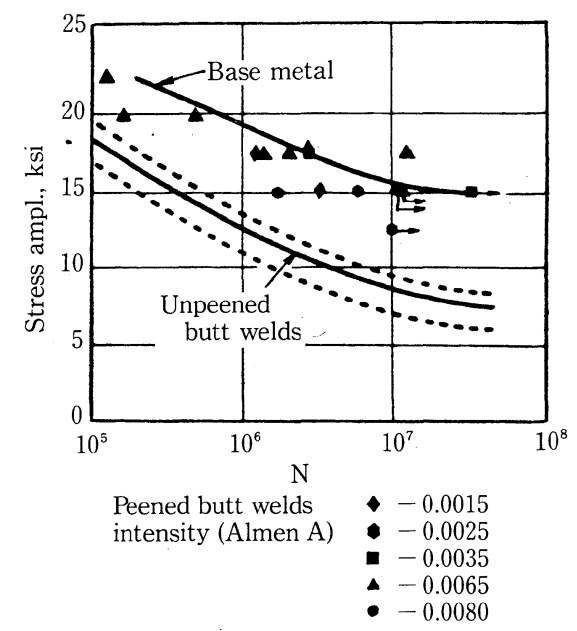

Fig. 22 Effect of brush shot peening on fatigue performance of 5086-H116 GMAW butt weldments. ${ }^{27)}$

に母材よりかなり低いのでその向上を，後者は 5086-H 321 板隅肉溶接継手の余盛端における応力集中軽減を狙 つたものであり，それぞれ 100 ton 級の Surafce Effect Ship のき裂発生部の補修または溶接構造鉄道無蓋貨 車 に適用して効果をあげたといら。

Hardy Jr. ら ${ }^{27)}$ の供試材の板厚は $1 / 4^{\prime \prime} ， 5 / 8 ”$ および $1^{\prime \prime}$ の 3 種類で, 溶加材 5356 を用いたミグ溶接 (GMAW) と 電子ビーム溶接 (EBW) を行つている。疲労試験は共振 型平面曲げ $\left(5 / 8\right.$ "厚突合せ一余盛削除, および $1 / 4^{\prime \prime}$ 厚 $\mathrm{T}$ 型隅肉—Fig. 21 参照, 試験速度 $1,800 \mathrm{cpm}$ ) と片持ち回 転曲げ ( 1 "厚，旋削仕上げ， $1,400 \mathrm{rpm})$ を行い，鋳鋼シ ヨットブラシとタングステン・カーバイド・ショットブ ラシを用いてピーニング加工を施している。実験結果の 1 例はFig.22に示す。余盛削除した GMAW突合せ継手 の疲労強度は母材の值 $\left(15 \mathrm{ksi}, \mathrm{N}=10^{7}\right)$ まで回復し, $\mathrm{T}$ 型隅肉継手では $5 \mathrm{ksi}$ が10 ksi に向上した。 EBW 突合せ 継手の回転曲げ疲労強度は母材と同程度であるが，平面 曲げの場合は微小気孔があるため GMAW 継手の值と大 


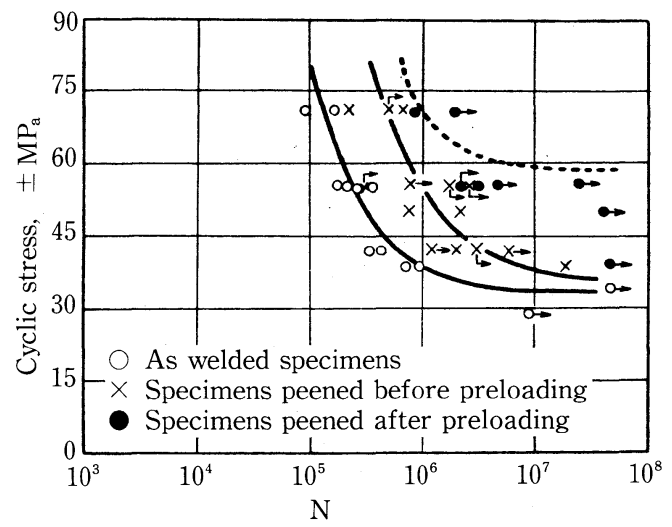

Fig. 23 S-N curves for specimens containing transverse fillet welds. (All specimens preloaded to a stress of $+13.8 \mathrm{MPa}) .{ }^{28)}$
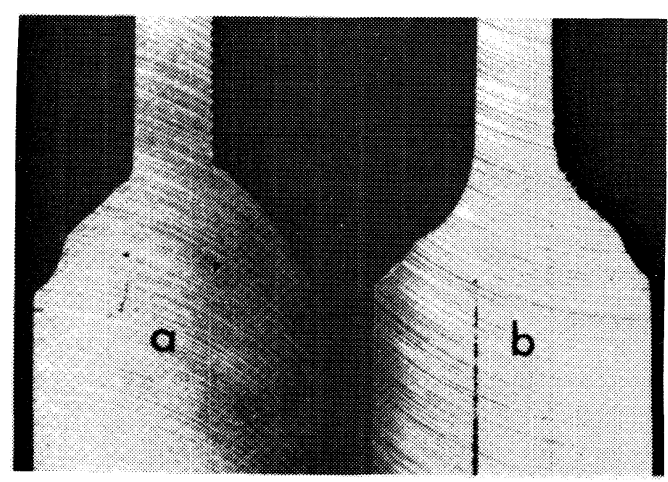

Fig. 24 Profiles of (a) untreated and (b) dressed fillet welds. ${ }^{28)}$

差なかつた。なお, 実地への適用は $9 / 16^{\prime \prime} \times 1^{\prime \prime}$ タングステ ンカーバイト・フラップブラシを用い，アルメンゲージ のアークハイト0.0035 0.0080の条件で行つている。

Polmear ${ }^{28)}$ は溶加材5356を用いてミグ溶接した突合せ 継手 (板厚 $8.8 \mathrm{~mm}$ ) と長手方向隅肉継手 (板厚 $6.3 \mathrm{~mm}$ ) について Janson Needle Gun を用いてピーニング 加工

(50 mm溶接長を約 $10 \mathrm{sec}$ で処理) を施し, 疲労寿命に 及ぼす影響を検討した。疲労試験は $R=0.5$ および 1.4 と し, 余盛端のピーニングは予荷重を負荷する前または後 で施している。疲労試験結果は Fig. 23 に示すように, いずれの場合もピーニングは効果的であつたが，特に予 荷重を負荷後の效果が著るしい。さらに，ティグ・ドレ ッシングの効果も検討しており，余盛端の切欠効果の減 少(Fig. 24 参照) のため，突合せ継手の場合が1.9 3.3 倍, 隅肉継手で $3 \sim 5.1$ 倍, それぞれ平均疲労寿命が向 上し, S-N 曲線を Fig. 25 に示す。ティグ・ドレッシン グは実地に適用していないが，ピーニング加工より効果 的であるかも知れないと述べている。

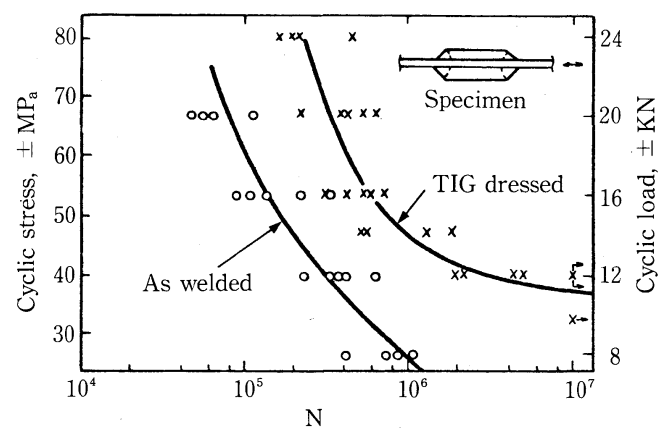

Fig. 25 S-N curves for untreated and TIG dressed transverse fillet-welded specimens (Prestress +13 MPa). ${ }^{28}$ )

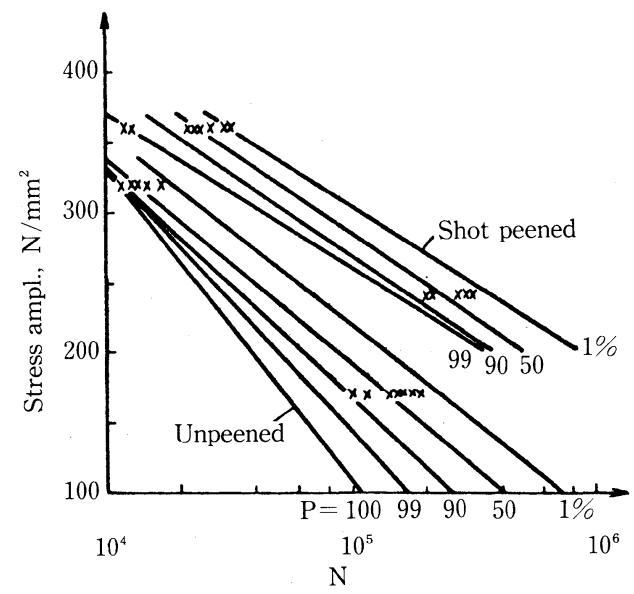

Fig. 26 S-N curves of unpeened and shot peened (glass $\phi 0.84 \mathrm{~mm}, 2 \times 98 \%$ ) welded joints of $\mathrm{AlZn} 4.5 \mathrm{Mg} 2$ alloy. ${ }^{29)}$

なお，W. Köhler ${ }^{29)}$ は $\mathrm{AlZn} 4.5 \mathrm{Mg} 2$ 合金について 溶接部の耐応力腐食割れ性を改善するためショットピー ニングの影響を検討しており，その実験の一部として軸 方向疲労試験 $(R=0.1,30 \mathrm{~Hz})$ を行つている。Fig. 26 に示すように疲労強度が著るしく改善され，またショッ トピーニング後 ( $\phi 0.84 \mathrm{~mm}$ ガラスビーズ, A2, 0. 16)の 圧縮残留応力は熱影響部においてー280 N/mm² に達し, 表面より深さ $0.08 \mathrm{~mm}$ に最大值がある。

\section{5. 各種溶接継手の疲労強度}

\section{1 船殼構造用継手の疲労強度}

J. E. Beachらは船殻構造に用いる実物大の溶接継手に ついて疲労挙動を検討しており ${ }^{30)}$ ，船底縦桁の連続また は不連続組立継手構造を評価するのが主目的である。供 試継手は Fig. 27 に示す 8 種類で, 5086-H 116合金（厚 さ1/4"が標準) と溶加材5356を用いて造船所で溶接した ものであり，隔壁と縦桁のフランジ溶接部において長手 方向が $13 \mathrm{ksi}$ の引張残留応力, 溶接線方向が $11 \mathrm{ksi}$ 程度 


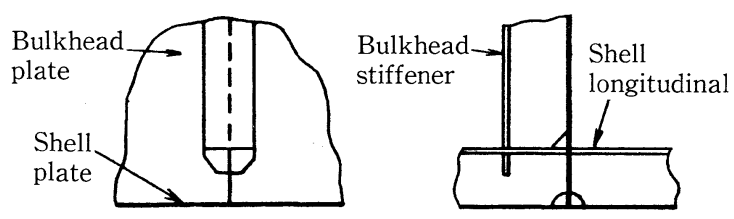

Configuration 1

Shell longitudinal discont.

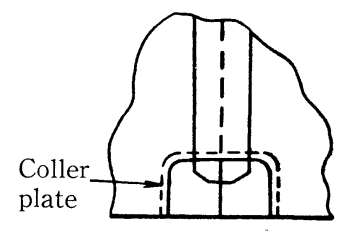

Configuration 2

Shell longitudinal Cont.
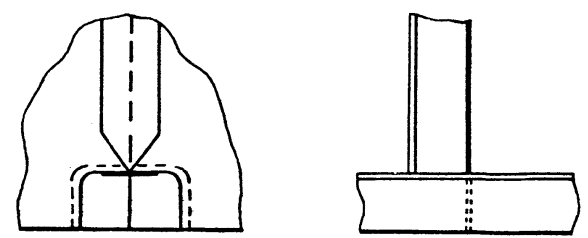

Configuration 6

Bulkhead stiff. flg. sniped to web
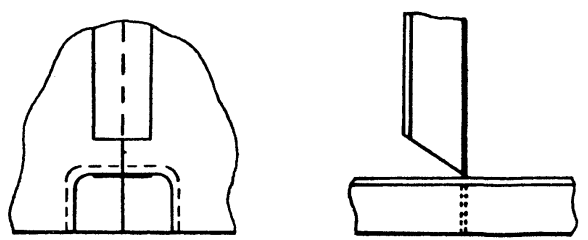

Configuration 7

Bulkhead stiff. sniped to web

Configuration 8 was similar to

Configuration 7 . Only the longitudinal stiffener was discontinuous.
Configuration 3 was geometrically identica to Configuration 2. Only it was originally made like Configuration 1. Then reworked
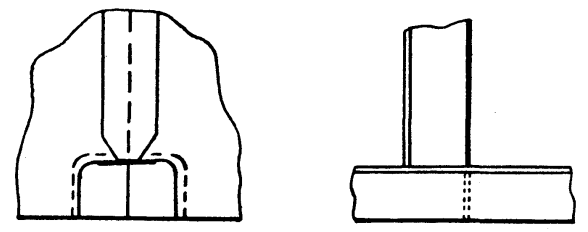

Configuration 4

Bulkhead stiff. flg. sniped to $1.25^{\prime \prime}$

Fig. 27 Structural detail configurations examined in test program. ${ }^{\text {30) }}$

の圧縮残留応力をそれぞれもつている。

一定振幅軸方向疲労は $R=0.1$ とし, 公称最大応力 8 ,

12, 及び16 ksiの 3 段階とし, Fig. 28 に結果を示す。変 動荷重疲労は船体中央部（縦桁の曲げ）と船首近傍（衝 撃波浪）の25年間にわたる荷重頻度曲線を検討してそれ ぞれ曲げ荷重疲労および軸荷重疲労を行い, 結果の一部

を Table 8 に示す。

各継手の疲労寿命を比較すると, 高応力では差が余り ないが，低応力の場合は負荷を連続して伝達する構造の ものが不連続なものの 2 倍以上の寿命をもち, 継手構造 としては Fig. 27 における No. 7 と 8 が望ましい。

\section{2 管材溶接継手の疲労強度}

F. Mang $ら^{31)}$ は管材溶接継手の疲労試験 $(R=0.1)$ を 実施している。供試材は $\mathrm{AlZn} 4.5 \mathrm{Mg} 1 \mathrm{~F} 36$ と AlMgSi 0.5 F22合金角管で, 溶加材 S-AlMg 4.5 Mn または SAlSi 5 を用いたミグ溶接継手である。

疲労試験は Fig. 29〜31 に示す隔壁板をもつ突合せ継 手と十字継手について行い，前者の場合は隔壁部の弾性 が疲労強度に影響を及ぼし, かつ偏心率等の問題を指摘
している。後者は構造材の幅の比 $\mathrm{b} / \mathrm{B}$ が大きくなるにつ れて疲労強度が向上するが, $b / B=1$ の場合は実験中で ある。K型継手では Fig. 31 に示すようにブレースの間 隙比 $\mathrm{g} / \mathrm{b}$ の影響を検討しており，50\%オーバーラップが 最高の疲労強度をもつ。この場合, き裂の発生位置は才 一バーラップの程度と関係し， $\mathrm{g}$ があるとブレースの付 根である。肉厚比 $T / t$ (ただし, $T:$ 桁材の肉厚, $t:$ ブ レースの肉厚) が大きく， $\mathrm{g}$ がある場合はオーバーラッ プより疲労強度が高くなるが, さらに実験継続中とのこ とである。

なお，鋼材 $\mathrm{S}_{\mathbf{t}} 37$ を用いた継手との比較が行われてお り，アルミニウム合金は縦弾性係数が低い結果として継 手の変形が大きいから, 疲労挙動が鋼と異なると述べて いる。

\section{3 構造材の疲労寿命の予測}

J. Jaccard は直線的破壊機構モデルから $6005 \mathrm{~A}-\mathrm{T} 6$ お よび295-T6 合金（鋳物）の S-N 曲線をシミュレートし ており ${ }^{32)}$ ，き裂進展現象にもとずいて，き裂進展速度， 欠宿の幾何学的形状および応力範囲を疲労寿命の予測に 


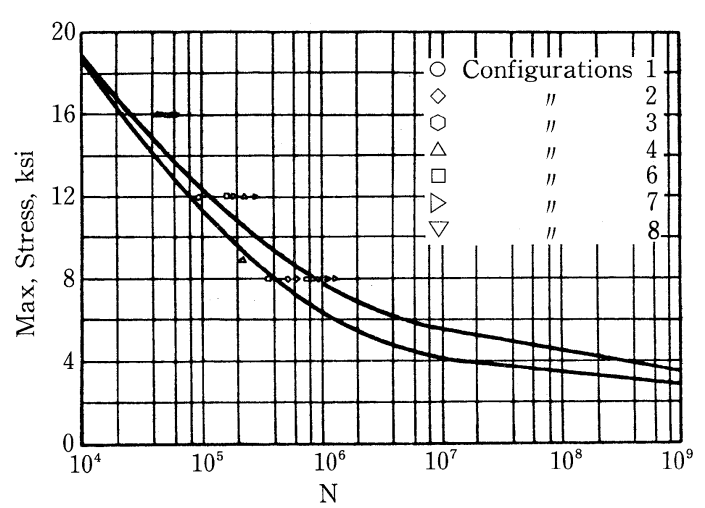

Fig. 28 Constant amplitude tension test data compared to original $\mathrm{S}-\mathrm{N}$ curves. ${ }^{30)}$

Table 8 Results of Variable Amplitude Bending Tests. ${ }^{30)}$

\begin{tabular}{ccc}
\hline $\begin{array}{c}\text { Specimen } \\
\text { Type }\end{array}$ & $\begin{array}{c}\text { Approximate No. } \\
\text { Years to } \\
\text { Crack Initiation }\end{array}$ & $\begin{array}{c}\text { No. Years } \\
\text { to Failure }\end{array}$ \\
\hline B-1-1 & 23 & $(26.6)^{*}$ \\
B-1-2 & $30+$ & $(28.4)^{*}$ \\
B-2-1 & 13 & $(32.0)^{*}$ \\
B-2-2 & 8 & 85.8 \\
B-4-1 & 20 & 60.3 \\
B-4-2 & 10 & 54.3 \\
B-6-1 & 12 & 125.0 \\
B-6-2 & 18 & 101.8 \\
B-7-1 & 80 & 125.0 \\
B-7-2 & 25 & 68.4
\end{tabular}

*These specimens were not tested to failure.

Numbers shown indicate when test was stopped.

** Lifetime midship bending stress spectrum (primary hull girder bending).

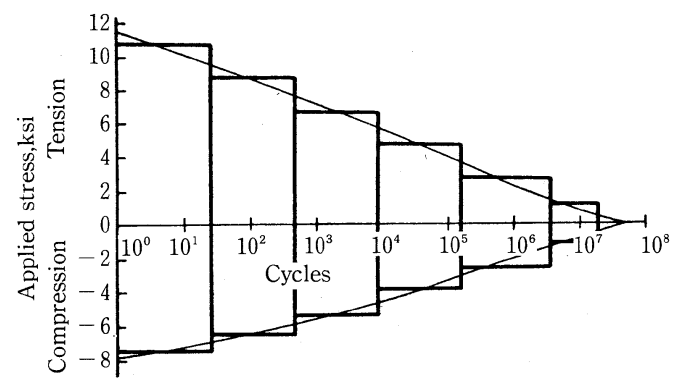

用いている。すなわち, $d a / d N$ は $\Delta K$ と関係 し, $\Delta K$ そ れ自体は欠陥 $(a, Y)$ および応力 $(\Delta \sigma, R)$ の結果とし て表され ((1)式参照), き裂の幾何学的函数である $Y$ は直 線的破壊機構モデル ${ }^{33)}$ で定義される。

$\Delta K=\Delta \sigma \cdot \sqrt{a} \cdot Y$

$d a / d N=C[\Delta K]^{\mathrm{n}}$

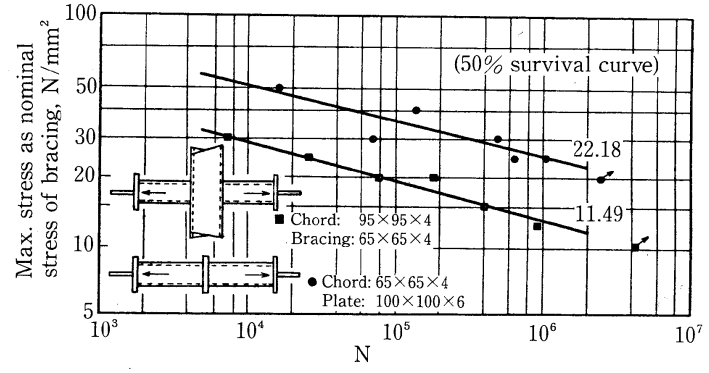

Fig. 29 S-N curves for butt joint with diaphragm plate and cross joint (AlMgSi0.5 F22, $\mathrm{R}=0.1)$. $^{31}$ )

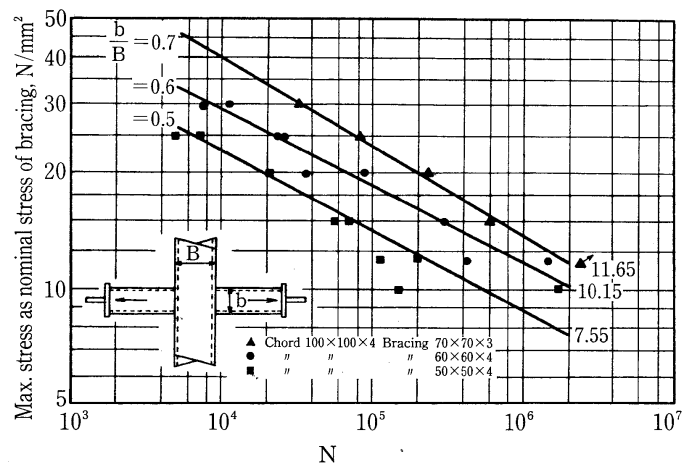

Fig. 30 S-N curves for cross joints (AlZn $4.5 \mathrm{Mg} 1$ $\mathrm{F} 36, \mathrm{R}=0.1) .{ }^{31}$

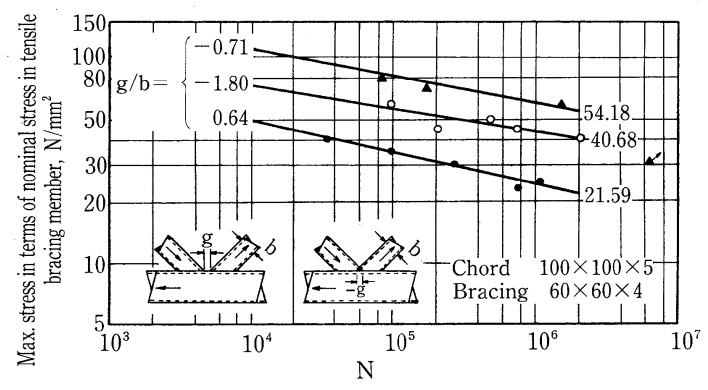

Fig. $31 \mathrm{~S}-\mathrm{N}$ curves for $\mathrm{K}$-joints $(\mathrm{AlZn} 4.5 \mathrm{Mg} 1$ $\mathrm{F} 36, \mathrm{R}=0.1) .{ }^{31)}$

$$
\Delta N=\int_{a_{1}}^{a_{2}} \frac{d a}{C[\Delta K]^{\mathrm{n}}}
$$

疲労寿命は(2)式で表されるから,初期き裂サイズ $a_{1}$ が $a_{2}$ に進展するまでの繰返し数を検討すればよい。き裂進

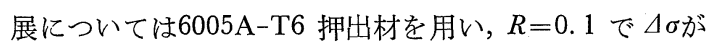
6 条件 $\left(\mathrm{a}_{1}=0.03 \sim 1.51 \mathrm{~mm}\right)$ の結果を述べている。 き裂発生部の観察や, 結晶粒組織の違いが $\Delta K$ に及ぼす 影響を検討した結果から， S-N 曲線 シミュレーション (コンピュータ・プログラム FAGRO ${ }^{34)}$ にる) には正 常結晶粒組織のき裂進展速度とシングルエッジ・クラッ クモデルを用いている。

シミュレートされた S-N 曲線を各種アルミニウム合 金押出ビームの実験点と比較したのが Fig. 32, 溶接ビ 
一ムに適用したのが Fig. 33 である。後者の場合は押出 ビームと同じ試験（ $R=0.1 ）$ であるが，シミュレート $\mathrm{S}-\mathrm{N}$ 曲線はそれと一致しない。溶接残留応力を無視した のが原因で，解析された残留応力 $80 \mathrm{~N} / \mathrm{mm}^{2}$ を最大，最 小応力に加えてシミュレートしたのが Fig. 34 であり, これは $R=0.7$ の場合に相当する。

その他の場合も含めてまとめると，6005A-T6 押出ビ ームのエッジクラック・モデルに用いた $\mathrm{a}_{1}$ は平均 0.3 $\mathrm{mm}$, 鋳物の場合はその 3 倍であり, シミュレートされ た S-N 曲線は各実験点のばらつきの下限に位置する。

\section{4 その他の継手の疲労強度}

(1) 圧接溶接継手 $\mathrm{Al}-\mathrm{Mg}-\mathrm{Si}$ 合金押出形材を長手方 向に熱間圧接してトレーラーや海上コンテナのパネルを 製造するアルフォージ法を用いて，船舶用パネルを製造 する場合の問題点が W. A. Palkoら ${ }^{35}$ によつて検討され ている。供試材は5456-H111 合金で，応力腐食割れを防 止するため, 圧接部に $399^{\circ} \mathrm{C} \times 30 \mathrm{sec}$ の局部加熱を施して いる。 $R=0.01$ における疲労強度は母材上り低い值を示 すが，ミグ溶接継手より高く，また，圧接のままと 246 ${ }^{\circ} \mathrm{C} \times 24 \mathrm{hr}$ 焼なまし材との間に差が見受けられない。

(2) 構造用トランジション継手 構造用トランジショ ン継手に関する軽金属溶接構造協会 STJ 委員会の報告

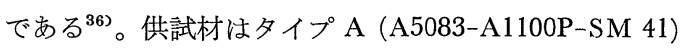
と B (A3003P-TP 28-SM41)の 2 種類で，継手の接合部 中央に半円型をたはU 型切欠をつけた場合の片振り疲労 試験を行っている。疲労破壞はアルミニウム側（ウェブ プレート，または隅肉部）に発生し，爆着による接合部 は異常なかつた。両タイプの継手間に疲労強度の差や, 切欠による相違もない。

(3) クリンチ継手 J. Henning らは Homax社のクリ ンチングを用い, Anticorodal-120(AlMg0.4Si1.2) 合金 $1.25 \mathrm{~mm}$ 板についてクロスクリンチ 3 点打ち（重齐代 40 $\mathrm{mm}$, 幅 $70 \mathrm{~mm}$ に 3 点並列打ち) の疲労強度 $(R=0.1)$

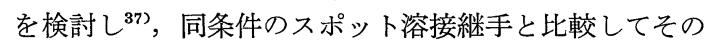
優位性を述べている。

（4）熱影響部の低サイクル疲労 アルミニウム合金熱 処理材または加工材の溶接部近傍は強度低下が抒きてお り，長手方向溶接線をむつ部材の場合は熱影響部による 強度低下を断面数值の減少または細長比の増加として処 理している。また，静的サービス荷重内の負荷でも熱影 響部は塑性ひずみによる疲労き裂が発生しやすい。D. Kosteas $^{38)}$ は長手方向に溶接線をもつ AlMgSi 1 F 32 (6082)合金 I およびT型材について軸力または曲げを受 ける場合の塑性疲労を検討している。非溶接部，熱影響 部の応力ーひずみ線図をDIN 4113 および塑性理論に従 つて求め, これをべースとして Manson-Coffin, Morrow らの塑性疲労実験式を比較検討し，熱影響部の塑性疲労

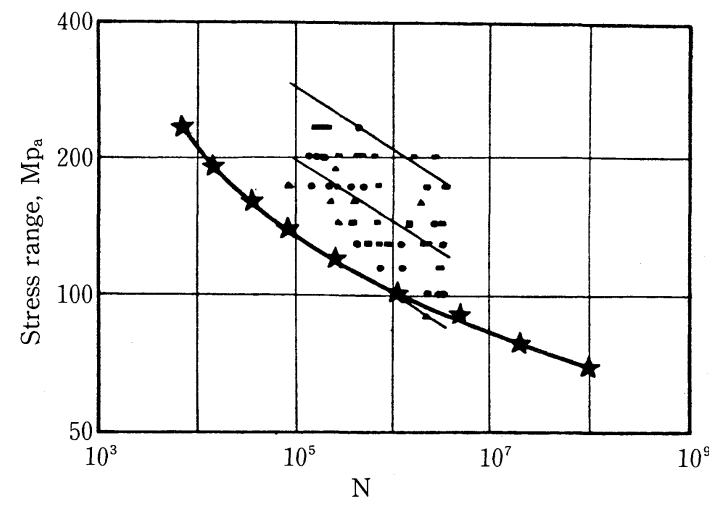

Fig. 32 SN-simulation extruded beams, base metal, $R=0.1, H=220 \mathrm{~mm}^{32}$ )

$\star$ : (Cal. : $N=1,084,000$ Cycles, ${ }_{S} R=102 \mathrm{~N} / \mathrm{mm}^{2}$, $a=0.2898 \mathrm{~mm}, C=10.0 \mathrm{~mm}$ )

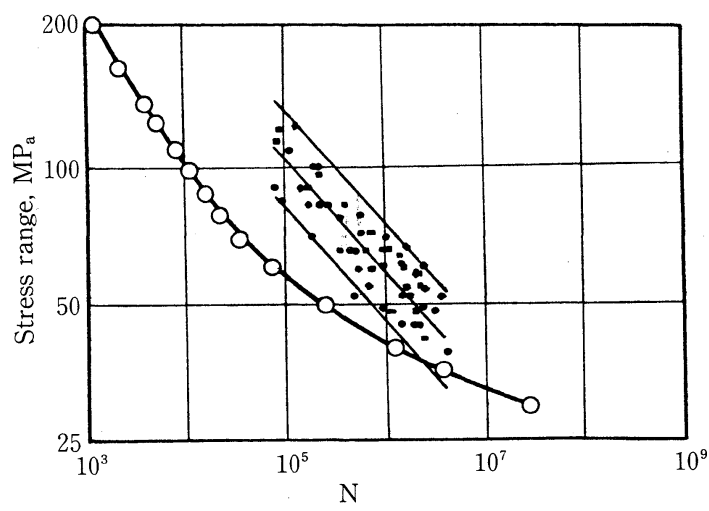

Fig. $33 \mathrm{SN}$-simulation butt-welded beams, $R=$ 0.1 . No residual stresses. ${ }^{32}$ )

(Calibrat.: 3,458,000 Cycles, ${ }_{s} R=36 \mathrm{~N} / \mathrm{mm}^{2}$, $a=2.129 \mathrm{~mm}, C=10.0 \mathrm{~mm}$ )

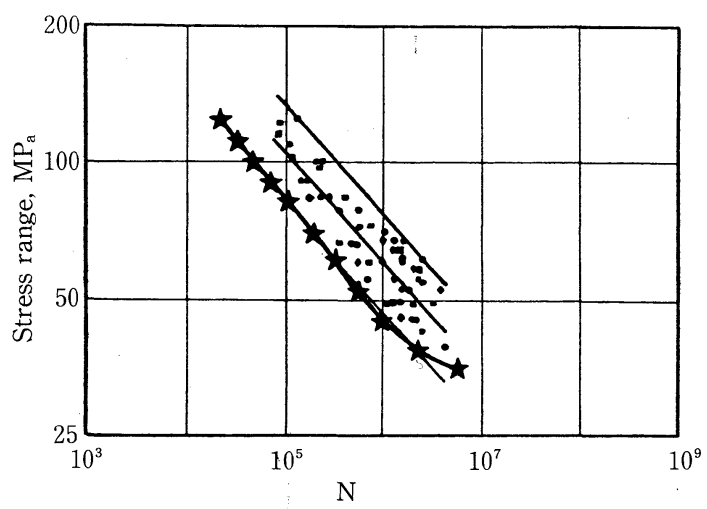

Fig. $34 \mathrm{SN}$-simulation butt-welded beams, residual stresses included, $R=0.7 .^{32}$ )

$\star$ (Calibrat.: $3,458,000$ Cycles, ${ }_{s} R=36 \mathrm{~N} / \mathrm{mm}^{2}$, $a=0.4162 \mathrm{~mm}, C=10.0 \mathrm{~mm}$ ) 
寿命を算出している。

\section{6. おわりに}

第 2 回アルミニウム溶接物国際会議で発表された論文 の中から疲労に関係するものを要約した。趨勢として次 のことがいえる。

(1) 欧米, 特に欧州においてはアルミニウム構造規格 の改正もしくは制定が進行中であり，鋼とアルミニウム 合金の相対的疲労強度が同じといらことから, 疲労設計 規格は鋼構造規格のそれに準じるものになろう。また， CAFDEEにより統計的处理された疲労データがこれらに 活用されよう。

(2) 軸方向疲労試験で片振りまたはそれ以上の平均応 力をもつ場合の疲労データが多く，これは溶接部の引張 残留応力を考慮しているためである。なお，P-S-N線図 表示が多い。

以上に招いて，興味媣いのは S. J. Maddox の提案で ある。「鋼構造設計 S-N 曲線を縦弾性係数の比 3 で除す ればアルミニウム合金に適用できる」ということで，大 局的には実験データからみて問題がないようであるが， 個々の実験では材質による差が現れている。また引張残 留応力が溶接部に存在することも既知であるが，実際の 構造物溶接継手では測定が難かしい。いずれにしても充 分管理された研究室的規模のものと現場との相違が問題 であり，実物大溶接継手の疲労試験が重要視されること になる。

我が国でも溶接継手の疲労試験は軸方向片振り, むし くはそれ以上の平均応力をもつ場合の疲労強度を求める ことに重点を挔き，それに破壊確率を表示することが必 要であり, 残留応力を考慮して耐久限度線図の片振りよ り右側を検討せねばなるまい。

\section{参 考 文 献}

1) 竹内勝治, 田中孝一 : 第 2 回アルミニウム溶 接物国際会議調查団報告書，3，軽金属溶接構 造協会, (Aug. 1982).

2) R. A. Kelsey, H. Nielsen: Aims and Scope of CAFEE, 2nd Inter. Conf. on Al. Weldments, May 1982 (München).

3) 竹内勝治 : 軽金属溶接, 20 (1982), 323.

4) W. W. Sanders, Jr., S. J. Maddox, D. Kosteas: Aluminium Fatigue Data-Description and Principles for Evaluation, 2nd Inter. Conf. on Al. Weldments, May 1982 (München).

5) F. Bastenaire: Comparative Report on Statistical Analysis of Three Sets of Fatigue Data, IIW Doc. XIII-1029-81, (1981).

6) T. R. Gurney, S. J. Maddox: A Re-analysis of Fatigue Data for Welded Joints in Steel, Weld. Res. International, 3 (4), I-54, (1973).
7) S. J. Maddox, D. Webber: Fatigue Testing of Weldments, ASTM STP 648, 159 (1978).

8) E. Haibach: Grundlagen und Weiterentwicklung des Betriebsfestigkeitsnachweiss für SchweiBverbindungen im Internationalen Regelwerk, DVS Berichte Nr. 57, 98 (1979).

9) D. Kosteas: Zur Systematik der Auswertung von Schwingfestigkeitsuntersuchungen bei Aluminiumlegierungen. Dissertation Univ. Karlsruhe, (1970).

10) S. J. Maddox: British Fatigue Design Rules for Welded Aluminium, 2nd Inter. Conf. on Al. Weldments, May 1982 (München).

11) T. R. Gurney: Welding Inst. Res. Bull. 115 (May 1976).

12) BS 5400, Steel, Concrete and Composite Bridge, Part 10 Fatigue (1980).

13) N. E. Frost, K. J. March, L. P. Pook: Metal Fatigue, Clarendon Press, 1974.

14) J. D. Harrison: Proc. Conf. Fatigue of Welded Structure, The Welding Inst. 194 (1971).

15) AWS Structural Welding Code, Steel, Design of New Bridge, (1979).

16) S. J. Maddox: Fatigue Design of Welded Aluminium Alloy Structures, 2nd Inter. Conf. on Al. Weldments, May 1982 (München).

17) S. J. Maddox, D. Webber: Detection and Measurement of cracks, Weld. Inst. Chap. 4 (1976).

18) S. Pearson: Nature 211 (1966), 1077.

19) J. D. Harrison: 2nd Inter. Conf. on Fracture, (1969), (Brighton).

20) S. J. Maddox, T. R. Gurney, A. M. Mummery, G. S. Booth: An Investigation of the Influence of Applied Stress Ratio on Fatigue Crack Propagation in Structural Steels, Weld. Inst. Rep. 72/1979/E, (1978).

21) S. J. Maddox: International Journal of Fracture, 11 (3), (1975).

22) W. W. Sanders Jr., S. M. Gannon: WRC Bulletin, No. 199 (1974).

23) V. I. Trufyakov: Auto. Weld., No. 5, 37, (1976).

24) S. J. Maddox: Proc. Conf. on Fatigue Testing and Design, Soc. of Environmental Eng., (1976).

25) U. Krüger, U. Priensnitz: The Effects of Discontinuities of The Fatigue Behaviour of Aluminium Welds, 2nd Inter. Conf. on Al. Weldments, May 1982, (Müncher).

26) U. Krüger: Fatigue Strength of Defective TIGwelded Joint of Thin-walled Aluminium Alloys, Colloquium on Al. and Its Alloys in Welded Constructions, Sept. 1981, (Proto).

27) R. R. Hardy Jr., M. E. Wells: The Effect of Fabrication Methods on The Fatigue Performance of Welded 5086-H116 Aluminum Alloy., 2nd Inter. Conf. on Al. Weldments, May 1982 (München). 
28) I. J. Polmear: Post-welded Treatments to Improve Fatigue Performance of Aluminium Alloy Welldments ments, Ditto.

29) W. Köhler: Improvement of Stress Corrosion Resistance of Aluminium Weldments by Shot Peening, Ditto.

30) J. E. Beach, R. E. Johnson, F. S. Koehler: Fatigue of 5086 Aluminum Weldments, Ditto.

31) F. Mang, O. Bucak: Carrying-over of Design Principles in Steel to Statically and Dynamically Loaded Aluminum Structures in Hollow Sections, Ditto.

32) R. Jaccard: Fatigue Life Prediction of Aluminum Structures Based on $S N$-Curve Simulation, Ditto.

33) R. Jaccard: Fatigue of Aluminium Structure, IABSE Conf. Proc. (1982).

34) R. Jaccard: "FAGRO a Computer Program to Evaluate Fatigue Crack Growth" devoloped by
Alluswiss, Language FORTRAN IV, Hardware: VAX $11 / 780$.

35) W. A. Palko: Evaluation of an Advanced Pressure Welding Method for Fabrication of Marine-Service Aluminium Alloys, 2nd Inter. Conf. on Al. Weldments, May 1982 (München).

36) K. Terasawa, I. Kurino, A. Kubota: Studies on the Properties of Aluminium Alloy-Steel Transition Pieces for Structural Transition Joint (STJ) of Ship Structure, Part II, Ditto.

37) J. Hennings, J. Maier: (A) Improvement of Spot Welding of Aluminum Sheet by Surface Treatments, (B) Comparison of Spot Welding and Mechanical Joining Processes, Ditto.

38) D. Kostears: Low-cycle Fatigue Damage Probability in the HAZ of Aluminium Weldments, Ditto. 